\title{
Assessment of municipal solid waste management system in Lae City, Papua New Guinea in the context of sustainable development
}

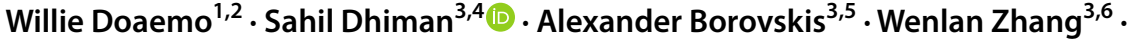 \\ Sumedha Bhat $^{3,7} \cdot$ Srishti Jaipuria ${ }^{3,8} \cdot$ Mirzi Betasolo $^{1}$
}

Received: 10 December 2020 / Accepted: 22 April 2021 / Published online: 29 April 2021

(C) The Author(s), under exclusive licence to Springer Nature B.V. 2021

\begin{abstract}
Lae City (LC) of Morobe Province is the second-largest city in Papua New Guinea. Due to the abundant natural resources it inherits, the resultant urbanization has led to an influx of the human population. This increase in population as a result of industrialization has led to increased municipal solid waste (MSW) accumulation. To address this exigent issue, which affects the nation's carbon footprint, it is imperative to review socio-economic and geographic factors to establish a feasible approach for managing MSW efficiently and sustainably. In the quest to achieve the same, the present assessment focuses on the 3 core waste management hierarchy systems to support sustainable development for LC by reviewing existing opportunities and challenges associated with the current MSW management system and the associated policies. The result shows that as a sustainable approach to MSW management of LC, a zero-waste campaign for resource recovery engaging all stakeholders can be implemented since the organic content of MSW generated in LC is as high as $70 \%$. Moreover, the dumping of MSW at the dedicated dumpsite site can be minimized if policies are strengthened and the proposed waste avoidance pathway is implemented strictly. In addition to this, to avoid the contamination of groundwater and recovery of methane, the use of the Fukuoka approach in the existing landfills has been suggested to capture leachate without any huge expenditure.
\end{abstract}

Keywords Municipal solid waste $\cdot$ Fukuoka method - Waste management hierarchy 3 core systems $\cdot$ Waste avoidance $\cdot$ Resource recovery $\cdot$ Landfill

\section{Introduction}

Lae City (LC), as the capital of the Morobe Province (MP), is the second-largest city in Papua New Guinea (PNG) with a population of 148,934 ("Districts of Papua New Guinea" 2014). The city expects a population influx and economic boom in the next few years due to urban drift and abundant resources (such as gas, oil, and mineral). However,

Sahil Dhiman

sahildhiman943@gmail.com; sdhiman_me19@thapar.edu

Extended author information available on the last page of the article 
great developing opportunities also bring the threat of massive waste generation. The poor municipal solid waste (MSW) management standards, insufficient funding, lack of policy and strategy guidelines lead to the fact that the main disposal of MSW in LC is landfill with open burning of waste. There is no waste reuse or recovery in the process (Wangi 2013). The practice will result in a waste of resources and cause odour, pollute groundwater, contaminate soil, and further pose significant threats to the health condition of local citizens. The fact of rapid urban population growth and mismanagement of local landfill sites in LC would further exacerbate the impact. Therefore, it is necessary and imperative to assess the current waste management system in LC to identify the neglected areas. The action should also consider socio-economic and geographic factors of LC when suggesting feasible approaches for local authority and stakeholders to improve the circular economy.

In this study, an effort has been made to propose an improved MSW management solution for LC based on the 3 core waste management hierarchy systems (3CWMHS), in order to reduce waste production, increase energy recovery rate, and alleviate the health risk to residents. It has been done by conducting literature reviews about MSW management and summarizing potential opportunities and challenges according to previous experiences. Currently, in LC, the barriers of developing countries including unavailability of sophisticated resources, external funding, and skilled workforce need to be considered.

\section{Methods}

The present study is designed to assess the sustainability of the existing MSW management system in LC of PNG and propose feasible recommendations for the local authority to improve the current system (Fig. 1). In order to achieve this goal, literature has been reviewed in the first place to learn from other experienced organizations and countries based on their strategy and method. Academic literature, including but not limited to journal articles, book chapters, and thesis, has been used for refining insightful theory and building concepts of the problem. Grey literature, such as websites with the topic of waste management in PNG, has also been introduced to gather missing data and finalize the proposing system. As a result of the assessment, policy recommendations are suggested based on the 3 core waste management hierarchy system (3CWMH), which is the modified version of conventional waste management hierarchy system (WMHS) proposed to accommodate the barriers such as less availability of sophisticated resources, external funding,

Fig. 1 Methodology used for the present study

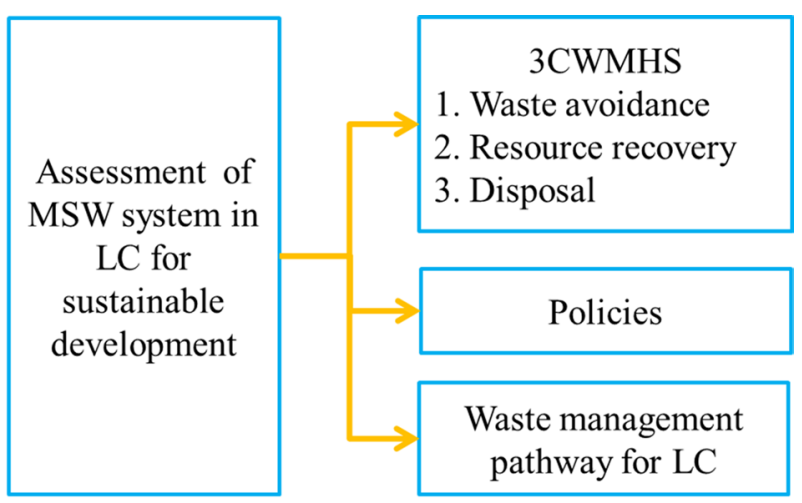


and skilled manpower present in LC. Also, a case study approach is chosen to clarify the detailed explanation of the strategy recommendations. The landfill site at LC, as the case study, can represent the MSW management system in PNG. By looking into the snapshot of the system, we could get an in-depth, rich, and contextualized answer of how MWS management should engage in the procedure of upgrading the landfill site at LC of PNG.

\section{Literature reviews}

The waste management hierarchy system (WMHS) (Fig. 2) as a waste policy guiding principle is extensively used by different agencies such as governments, educators, environmental groups, and industry because it takes into account the broader environmental, social, and economic impacts of a society or community waste system (Gertsakis and Lewis 2003). The WMHS system highlights waste prevention approaches being most preferable to waste disposal being the least desired option. In the current study, the hierarchy is separated into 3 core waste solutions including waste avoidance, resource recovery, and disposal. The following sections provide an in-depth scenario of this 3CWMHS system concerning the opportunities and challenges in LC.

Starting from the first core and the most important step to be favoured in the new practice of LC is waste avoidance; a dramatic reassessment and transformation in the production and consumption cycle are necessary to achieve economic growth and sustainable development while reducing the global ecological footprint (Pata 2021). As living standards improve for emerging nations, their waste footprint also increases, and without national policies and regulations, this can be unsustainable (Ferronato and Torretta 2019). In achieving waste prevention, a robust education campaign must be developed and deployed in the community. This will enable an understanding of their waste characteristics and then provide a platform for strategies in waste avoidance and reduction (Kalambura et al. 2015). From a planning point of view, it is very important to estimate and characterize the total amount of waste generated in LC because equipment and facilities are

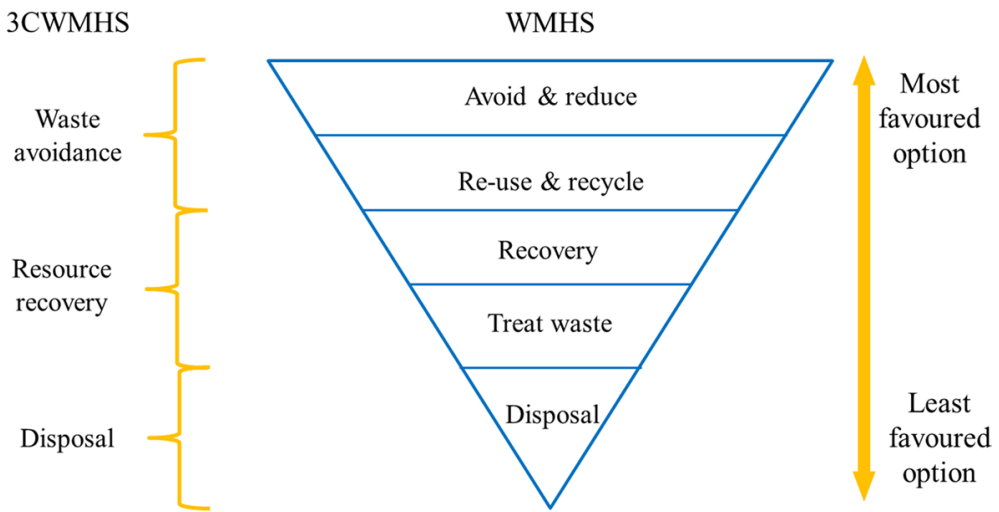

Fig. 2 Waste management hierarchy system (WMHS) and the modified 3 Core waste management hierarchy systems (3CWMHS) concerning challenges and opportunities for Lae city 
provided and designed based on the amount of generated waste (UNESCAP 2010). Table 1 shows a recent record of such studies concerning MSW estimation and characterization.

From Table 1, it can be observed that a developed country is more likely to have a higher organic fraction in total MSW (Pujara et al. 2019). A developed country, on the other hand, is likely to have a majority of non-organic waste due to the high standard of life and availability of every commodity well packaged, which leads to a substantial waste in the form of packaging as seen in the case of Sydney metropolitan area, Australia (Sunayana et al. 2021). In view of this, (Bortoleto et al. 2012) developed a system for household waste prevention behaviour based on a survey. Perceived behaviour control and personal norms were found to be the most significant predictors, followed by moral obligations. Waste recovery practices and source separation of household waste are some of the preventive actions of waste generation (Chung and Poon 1999). (Bernstad et al. 2011) studied waste (household) source separation in southern Sweden and revealed that with optimum sourceseparation of all recyclables, the existing net contribution to global warming could be shifted to a net avoidance. Furthermore, disposal of food waste in paper bags for dispersed drying before recycling helps in a larger net avoidance of global warming (Bernstad and la Cour Jansen 2012). (Kumar and Agrawal 2020) discussed the challenges that India facing in terms of MSW management. It was suggested that the recycling and disposal of MSW must be integrated more efficiently. For instance, resourceful solid waste, such as wet waste for compost/biogas processing and dry waste for energy plants, recycling, and reuse, is to be isolated at the source. As a result, it is important to ensure that as little waste as possible reaches dumpsites. Thus, being part of a developing country, the waste generation in LC can be managed if source separation can be carried at the household level. This will encourage the proper handling and recycling of the waste in the next stages of 3CWMHS. In addition to these techniques, waste avoidance can be implemented using various other approaches (Bulkeley and Gregson 2009). For instance, an integrated approach targets institutions such as governments, industry, educational organizations, and the local villages (Halkos and Petrou 2020). This can be undertaken through the establishment of educational centres on a municipal level, through the activities of NGOs, and in schools and universities (Arantes et al. 2020). Local media such as radio stations and posters can be an effective medium to ensure information is proliferated through the community. Likewise, (Tsai et al. 2021) identified three core factors for achieving sustainable MSW management in coastal and marine tourism cities: policy and legal frameworks, tourism policies, and stakeholder participation. Better governance is needed to attract additional investments for the reinforcement and growth of urban household MSW management in developing countries (Azevedo et al. 2021). Another impediment to waste reduction is a lack of overarching government policies, regulations, and laws for waste management as can be seen in Fig. 3. To ensure consistent and holistic implementation of waste management principles in a community like LC, top-down commitment on a national level is required (Chen and Chang 2010). Policies need to be developed in alignment with a few key principles such as the 'polluter pays', precautionary, and proximity principles (Kalambura et al. 2015).

Most of the above studies were conducted in developed countries, unlike the emerging nations which do not usually give high priority and resources to waste management capabilities or infrastructure which introduces challenges. With minimal economic instruments available to this industry, it is difficult to facilitate and implement the programs and systems to ensure sustainable and minimized waste production. By helping all stakeholders understand the relationships and interlinkages between poor waste management and adverse health outcomes to the population, coupled with a life cycle assessment of important waste systems, the investment can be more compelling in supporting the waste 


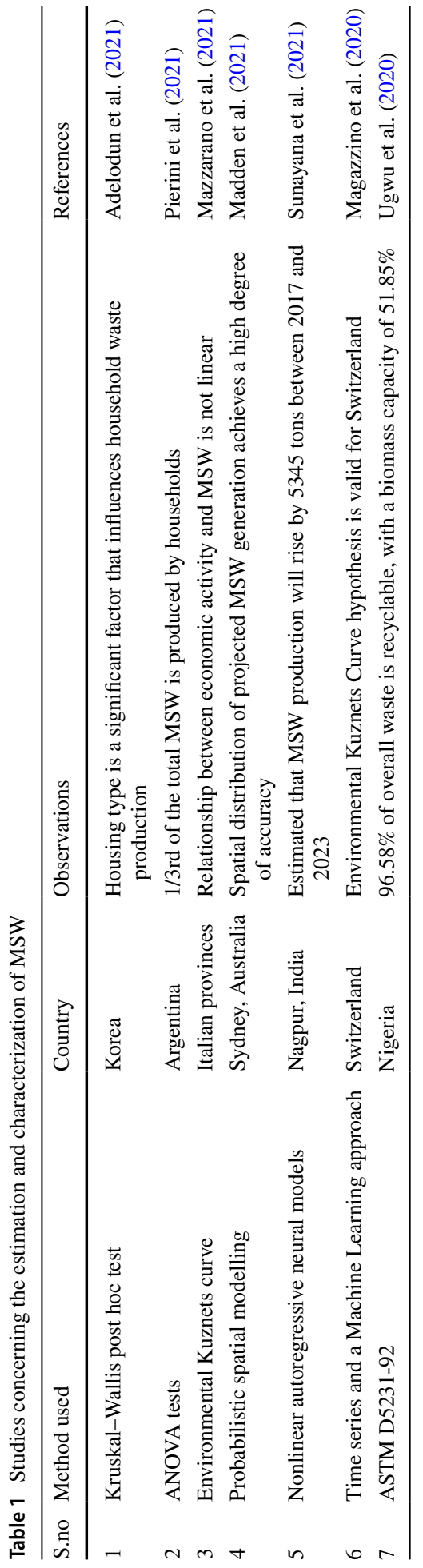




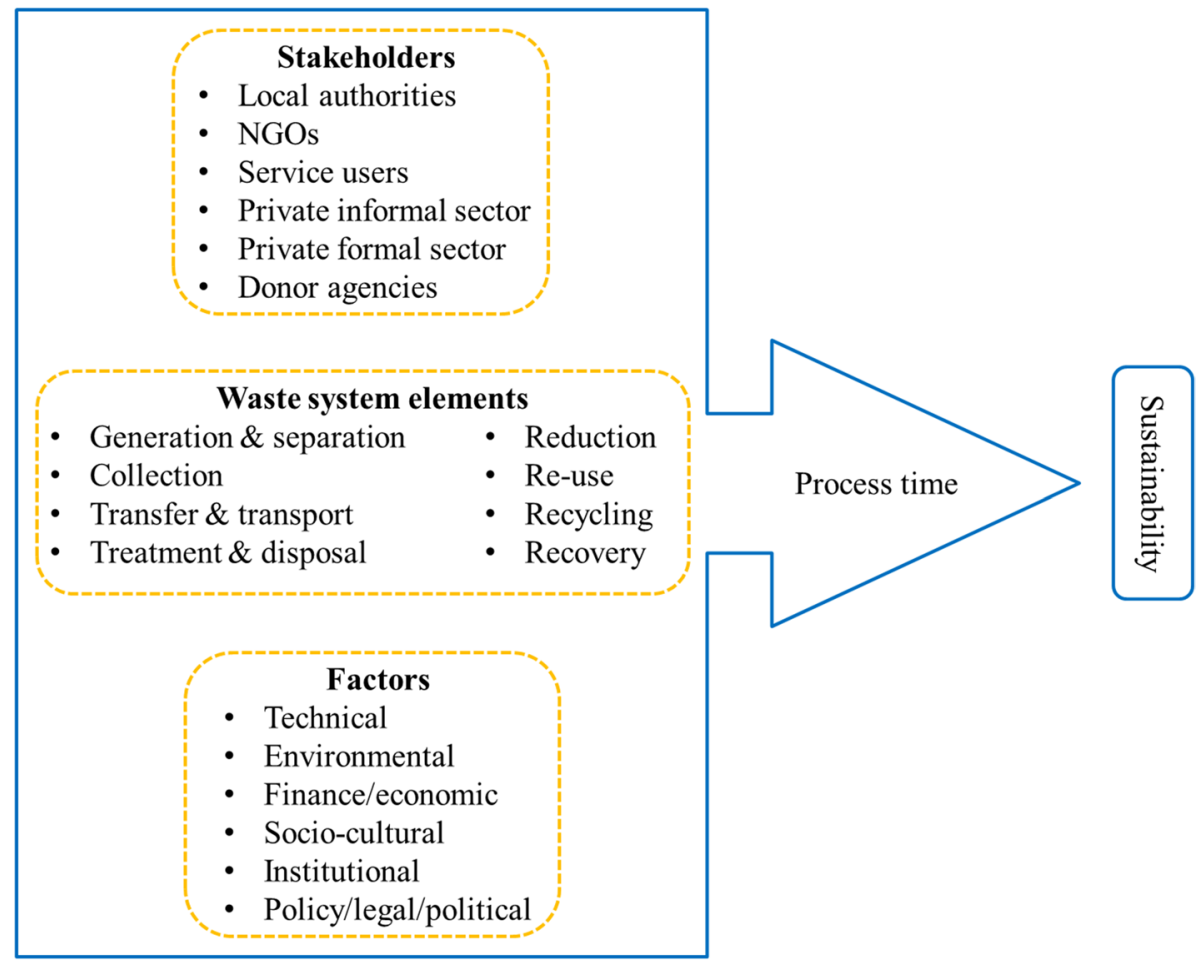

Fig. 3 Interrelationship of concerning bodies to regulate, and the imposition of policies related to avoid and reduce waste (Wilson et al. 2013)

industry (Ziraba et al. 2016). Where possible, governments should engage the support of international partners in establishing the foundational frameworks for LC's solid waste management practices.

The next step in the WMHS is to reuse and recycle waste, which is also classified as waste avoidance in the 3CWMHS proposed for LC. Organization for Economic Cooperation and Development (OECD) countries report approximately $27 \%$ organic waste fraction, all other global regions are 47-61\% (Hettiarachchi et al. 2018). This validates the argument that waste from emerging countries often has high organic content in total MSW as compared to the rest of the world, which in turn has implications on waste management decisions (Olay-Romero et al. 2020). It is essential to separate and recycle biodegradable organic material from the municipal waste stream to establish a sustainable waste management system (Rathore and Sarmah 2021). Of all of the recycling methods, composting of organic waste is recommended due to its environmental and economic benefits (Asensio et al. 2018). In emerging countries, composting has appeared as a vital technology to recycle biodegradable waste while generating a useful product for the residential waste generator or the market (Rastogi et al. 2020). As compared to the direct landfilling scenario only, the lower environmental burdens associated with the composting-landfilling scenario make it more environmentally attractive (Behrooznia et al. 2018).

Recycling and composting have many advantages for PNG as $>70 \%$ of MSW share are organic (Woodruff 2014). Material recovery instead of landfilling resources diverts the 
amount of waste stored and creates more space for non-recyclable materials that must be buried whilst also potentially generating valuable products and a revenue stream for people or organizations that sort and sell the waste (Lohri et al. 2014). To make recycling and composting possible in LC, peoples' cooperation is necessary. To reuse and recycle waste, the community needs to be trained to segregate the waste and be rewarded for it. When it comes to composting, people need to be educated about the benefits of keeping and storing the organic waste until it is fully decomposed to create fertilizer (Keng et al. 2020). At the household level, composting of organic waste can be fruitful in so many ways as it is a sustainable practice to divert organic waste from landfills (Agapios et al. 2020; Faverial and Sierra 2014).

Vermicomposting has emerged as a sustainable, economically viable, and easy method to stabilize household organic waste without any adverse effects to the environment or human health (Pirsaheb et al. 2013) as shown in Fig. 4a. In a study by (Soobhany et al. 2015a), a comparison of vermicomposting and composting was made based on the

(a)

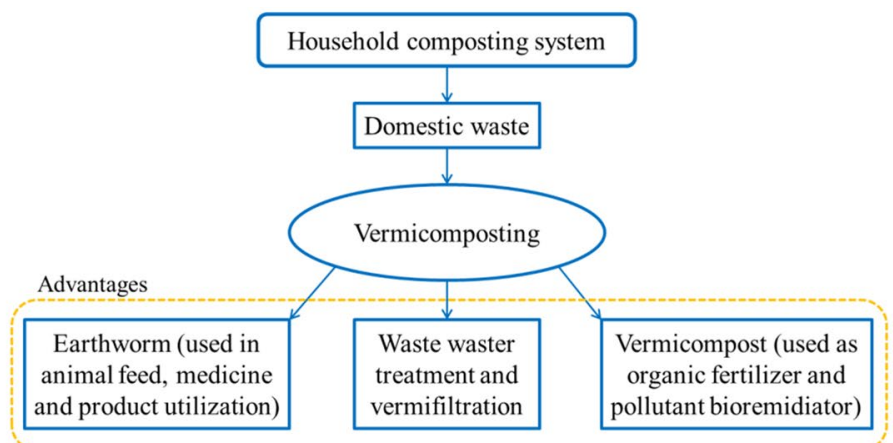

(b)

Large scale recycling and composting methodology in Lae city

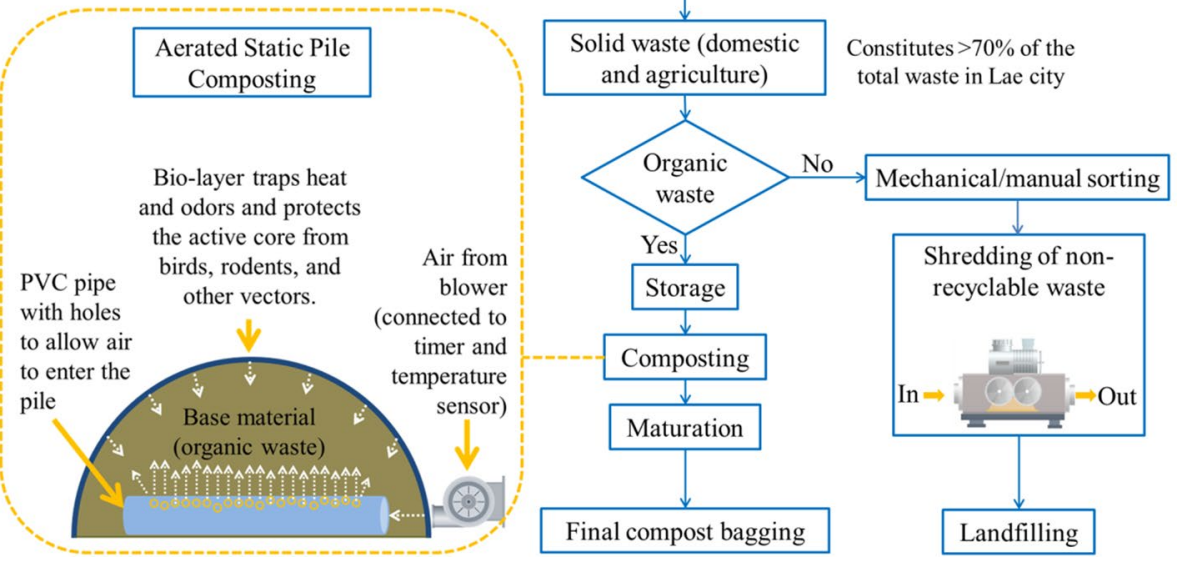

Fig. 4 a Suitable household composting system for Lae city (Sharma and Garg 2019) and b large scale composting methodology along with plausible composting technique considering socio-economic factors and resources available in Lae city 
recovery of nutrients and it was found that the vermicomposting increased $\mathrm{P}, \mathrm{K}, \mathrm{Mg}$, and $\mathrm{Na}$ and reduced $\mathrm{Cr}, \mathrm{Cu}, \mathrm{Co}, \mathrm{Zn}$, and concentrations in comparison to normal composting, due to the presence of earthworms (Soobhany et al. 2015b). In another study by (Soobhany 2018) an attempt to remediate metalliferous soil, data analysis showed that vermicompostextracts were more effective in lowering heavy metal concentrations. A study by (Bhattacharya et al. 2016) shows that vermicomposting coal ash and urban solid waste in a 1:1 ratio with cow dung is an environmentally beneficial proposition. Also, the acceptable time for maturation was calculated to be 75 days (Alidadi et al. 2016). In addition to the household composting system, there are many methods of composting organic waste on a large scale in the second seventh landfill (SSL) (which is one of the two existing landfill sites in PNG), such as onsite composting (He et al. 2019), in-vessel composting (Makan et al. 2020), aerated static pile composting (Luo et al. 2008), and aerated (turned) windrow composting (De Silva and Yatawara 2017). These are specific methods and can be employed as per the volume and availability of resources (land and manpower). In the current scenario, i.e., LC, there is the availability of land and manpower, but on the other hand, the unavailability of sophisticated equipment. Thus, in this scenario, aerated static pile composting is a promising method in SSL and is explained in Fig. 4b along with the composting methodology.

The fertilizing potential of MSW compost has been demonstrated by its high nutrient concentrations, particularly N, K, P, Ca, and Mg (Soobhany et al. 2015c). Nevertheless, in some areas, the percentage of inert impurities in the compost with a size larger than $2 \mathrm{~mm}$, such as plastic or glass, was seen to be excessively high, exceeding in some cases the legal limit. The source of such pollution lies in the composting inputs wherein the organic fraction of MSW showed high percentages of improper materials such as plastic (9\%) or glass (11\%) (Doña-Grimaldi et al. 2019). Accordingly, the sorting stage performance for the collection of the raw material must be improved, as must the refining process, since this does not remove the necessary amounts of these impurities from the final compost (Montejo et al. 2015). The composting process can be carried out in the dwellings of the community to fertilize the soil; this is a good way in which people can reduce their organic waste. Composting can be undertaken on a small community or residential scale with material recovered from the landfill, using a part for fertilizer and other treatment of the soil surrounding the landfill to reduce the leachate. This lowers the barrier to adoption for these processes in the community (Hopewell et al. 2009).

Recovery of energy is the second step in the 3CWMHS proposed for the LC. Energy can be recovered from the MSW generated within a community through various pathways such as thermal conversion (incineration, gasification, and pyrolysis), biological conversion (aerobic and anaerobic digestion), and landfilling (landfill gas) (Kumar and Samadder 2017). Non-organic and dry waste can be incinerated after the segregation process and combusted to produce energy (Table 2). Waste can be extracted from existing landfills to remediate the same landfill while producing a valuable energy solution (Yan et al. 2021). During waste decomposition, engineering landfill systems produce methane that can be captured, contained, and combusted to generate energy (Lou et al. 2011). All of these options are focused on reducing the environmental impacts of waste generation and waste management, thereby strengthening the economic value of waste (Sampat et al. 2021). Innovative treatment technologies such as gasification (Cai et al. 2021) and pyrolysis (Su et al. 2021) must be implemented. (Rathore and Sarmah 2020) suggested a circular economy-based MSW management structure in which household organic waste is converted into biogas and used as an energy resource. According to an analysis by (Michel Devadoss et al. 2021), the management of MSW in Malaysia is too reliant on landfilling as the 


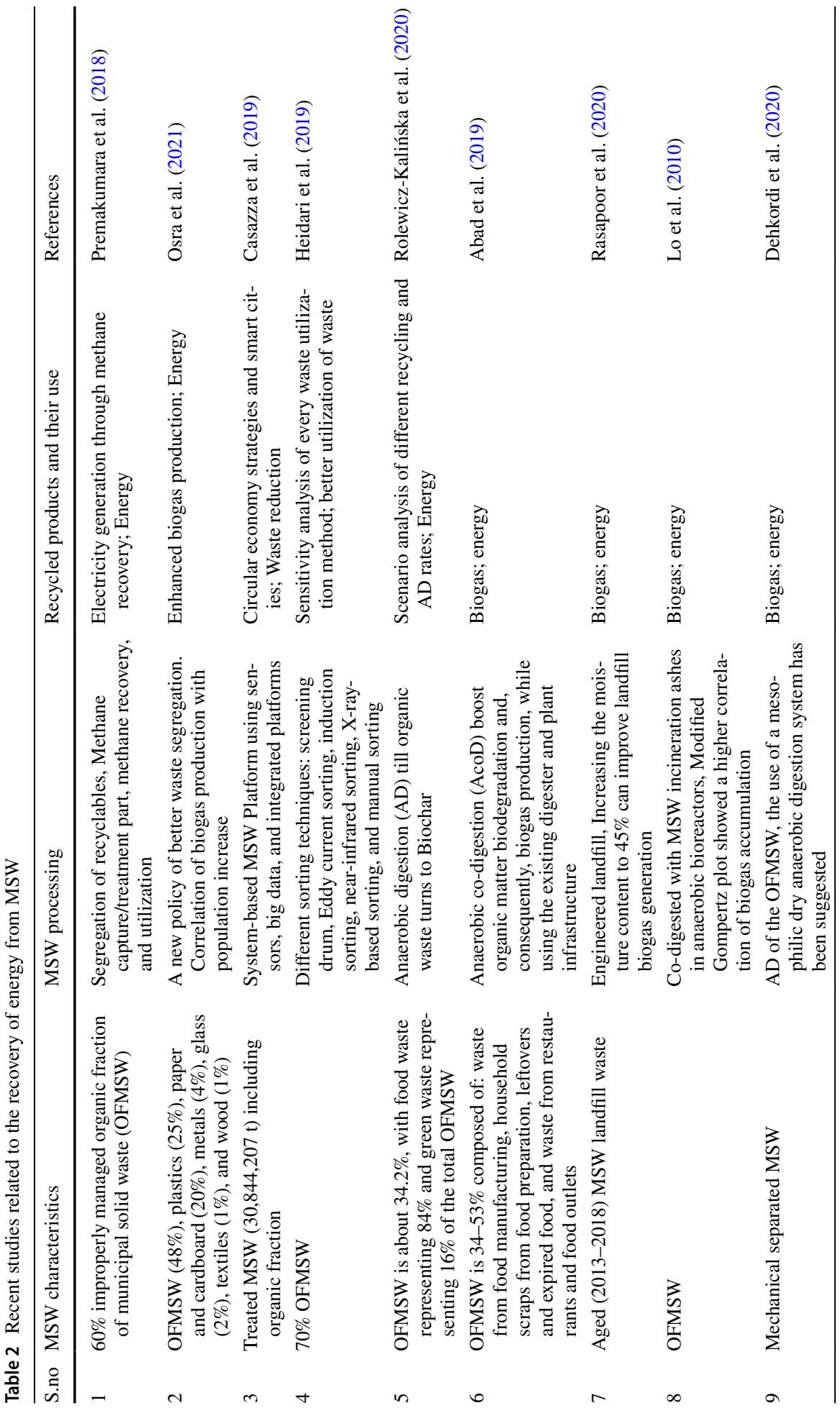




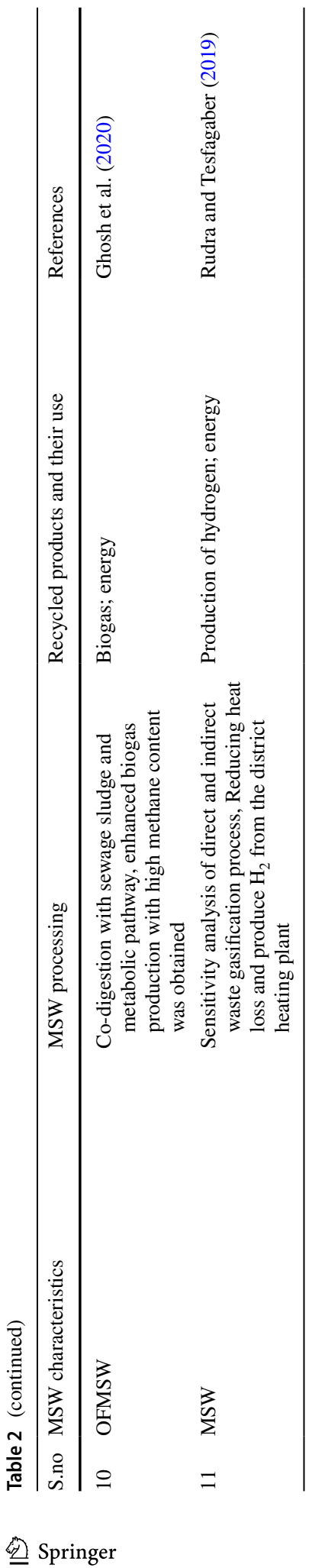




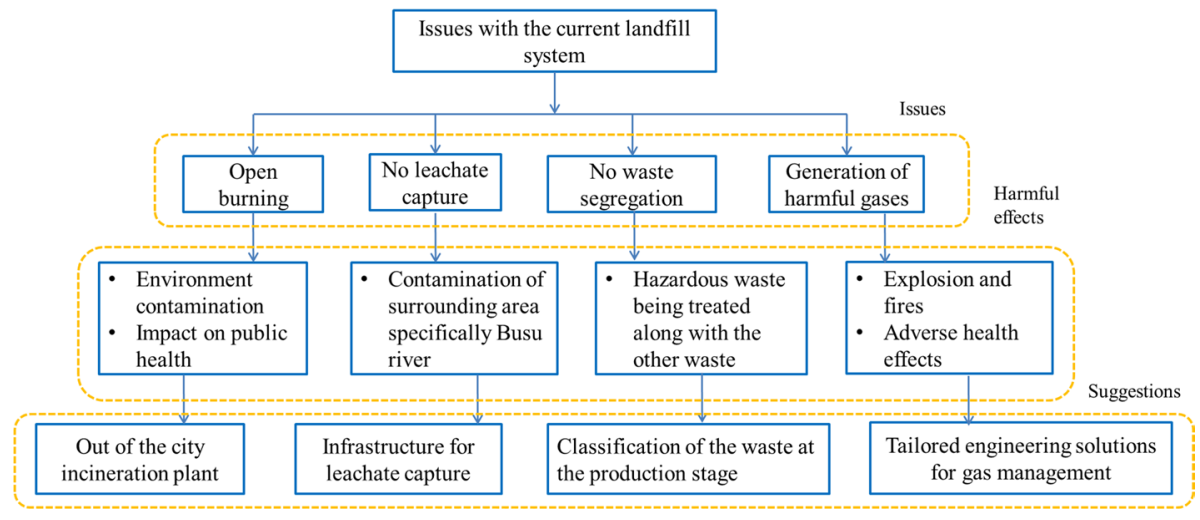

Fig. 5 Issues with the conventional and existing disposal of municipal solid waste in the second seventh landfill in Lae city

Table 3 Screening criteria of excavated municipal solid waste for the possibility of incineration

\begin{tabular}{llll}
\hline S.no & Waste type & Size range & Incineration possibility \\
\hline 1 & Coarse fraction & $>50 \mathrm{~mm}$ & Direct incineration \\
2 & Medium fraction & $18-50 \mathrm{~mm}$ & Incineration with additional fuel \\
3 & Fine fraction & $<18 \mathrm{~mm}$ & Cannot be incinerated \\
\hline
\end{tabular}

final mode of disposal. An integrated approach to manage MSW was proposed as the best option for reducing GHG emissions, with a goal of 40 percent recycling and 31.9 percent incineration by 2050 , resulting in a 64 percent reduction in GHG emissions.

Waste is currently openly burned at PNG landfill facilities and within the community. These uncontrolled combustion activities create a significant environmental burden with airborne pollution causing adverse health impacts to the community (Adam et al. 2021). This practice is not advised and infrastructure should be deployed to capture the energy from these activities. The current landfill scenario in LC is having several issues as shown in Fig. 5. It can be observed from Fig. 5 that the generation of landfill gases during the decomposition of organic waste is a concerning issue. Landfill gas often containing 50-60\% methane is generated on waste disposal sites receiving organic waste (Kale and Gökçek 2020). The regulation requires that the emission of this gas can be managed. However, very few suggestions exist as to monitoring management activities and the setup required to ensure management of emissions. Methane generated equals the sum of methane extracted, emitted into the atmosphere, oxidized, migrated laterally, and stored internally in the landfill (Larson et al. 2021). It has been shown that as a type of biogas, landfill gas could potentially be used in internal combustion engines, gas turbines, and industrial furnaces (Zeng et al. 2018). The utilization of these gases is only achievable if the landfill is an engineered system that incorporates specific changes in the existing design (Emmanuel et al. 2020). However, due to the improper design of landfills in PNG and lack of funding for the modification, it is required to prioritize the minimization of the gas emission into the atmosphere (Hogland and Marques 2010).

Specifically, for the incineration of MSW in LC, the excavated waste can be screened into different fractions as per Table 3. For instance, a coarse fraction $(>50 \mathrm{~mm})$ of the recovered organic masses can be incinerated directly, and sometimes a medium 
$(18-50 \mathrm{~mm})$ fraction can be incinerated with additional fuel. The fine fraction $(<18 \mathrm{~mm})$ cannot be incinerated because of its low calorific value and very high ash content. Along with these measures, it is important to find out whether the collected waste has a recycling opportunity and its corresponding value. The waste has three important characteristics to measure i.e., moisture, density, and calorific value. The first one compacts the waste and makes it harder to incinerate. The second one increases the weight of the waste, increases its volume, and indicates how easily the waste burns. The third is the energy contained within the waste fuel.

The last step is the treatment and disposal of waste which we categorized in the last and third core of 3CWMHS. Treatment of MSW involves the process of collecting and segregating waste (Lino and Ismail 2017). In the case of waste removal, contractors can be hired by the LC authorities to remove wastes twice a week. As income is directly related to waste generation, it would be useful to divide the city into sub-areas based on income per household to quantify the waste as shown in Fig. 6. Collection and transportation are usually the major parts of waste management costs, much more than landfill costs. Trucks, bins, and workers are an essential part of the process and represent a constant expense; the former requires capital expense and maintenance and the latter a monthly wage (Taşkın and Demir 2020). The key factor to be efficient at collecting and transporting waste is to reduce time and costs without sacrificing quality in the service. The trucks and routes taken to dispose of the waste must be optimized (Fig. 6). A truck needs to be easy to load and unload, should have an appropriate capacity for the amount of waste to be collected. It also needs to be able to adapt to the geography of the covered area so that the maintenance costs remain low. At the moment, the truck used for the disposal of waste in LC is appropriate. The primary collection of MSW will create new jobs.

After treating the waste as mentioned in the previous paragraphs, the leftover waste is sent for the final stage i.e., disposal. The final disposal of waste in LC is Second Seventh Landfill (SSL). SSL is not an engineered landfill, so it possesses some drawbacks due to its design. These drawbacks include leachate and methane gas leakage. Leachate is the liquid that has percolated through solid material and has leached out some of its constituents. Leachate is present in many landfills and without proper treatment, can permeate into the water supply or soil causing contamination leading to adverse health effects to the population. It varies widely in composition, depending on the age of the landfill and the type of waste that it contains. It usually contains both dissolved and suspended material. In the LC,

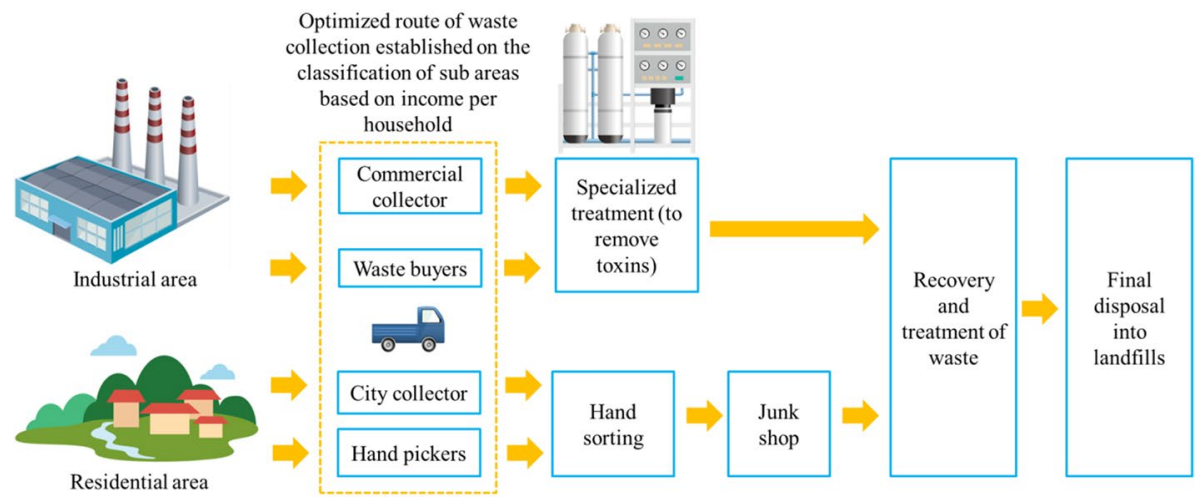

Fig. 6 Planned collection and processing of MSW proposed for LC 
a suitable method to remediate an existing landfill (SSL in the present case) is the Fukuoka method (Amiri et al. 2016), as shown in Fig. 7. This practice involves inserting a venting pipe into the landfill with a leachate collection pipe. It helps to reduce the emission of methane, and the leachate is collected due to gravity. The leachate is then treated through a multi-stage treatment plant - anaerobically, aerobically, and then released into a maturity pond before being discharged into the water PNG sewage system pond. Methane, on the other hand, can be reduced further by introducing bio covers to reduce the amount of methane being emitted at the SSL.

At the moment, there is no environmental and compliance monitoring of groundwater within the SSL. The methane being emitted into the air can be further reduced by putting compost containing the right microorganisms on the venting exhaust pipe, which can be installed to ensure the level of methane is within the compliance limit. There are several methods found in the studies to monitor Methane like the neural network prediction model (Ozkaya et al. 2007), tracer gas dispersion method (Scheutz and Kjeldsen 2019), surface emission monitoring, and genetic algorithms (Kormi et al. 2018). Methane can be monitored using drones to ensure it falls within the specified tolerance level. The leachate quality can be tested regularly for pH (Sanger et al. 2020), COD (Ferraz and Yuan 2020), and ammonia chloride (Schwarzwälder Sprovieri et al. 2020) along with the corresponding parameters of the groundwater system within the vicinity of the SSL. This testing is undertaken to ensure the leachate does not contaminate the drinking water system.

\section{Case study}

Papua New Guinea (PNG) is an emerging nation where the population has grown largely in the past decades. About $85 \%$ of the population lives in rural areas and depends on subsistence agriculture for their livelihoods (PAT 2003). One of the most densely populated areas in PNG is the Morobe Province (MP) which contains almost $9.3 \%$ of the country's total population ("Population Summary" 2018). Economically, MP is one of the most important regions in PNG due to an abundance of natural resources and a major port which caters to all exports including gold, copper, coffee, cocoa, livestock, poultry, forest fruits, and fisheries (Doaemo et al. 2020a, b; Kerf et al. 2019). This has also given rise to a major food processing industry, and MP is now PNG's manufacturing centre (Yoshinaga et al. 1991).

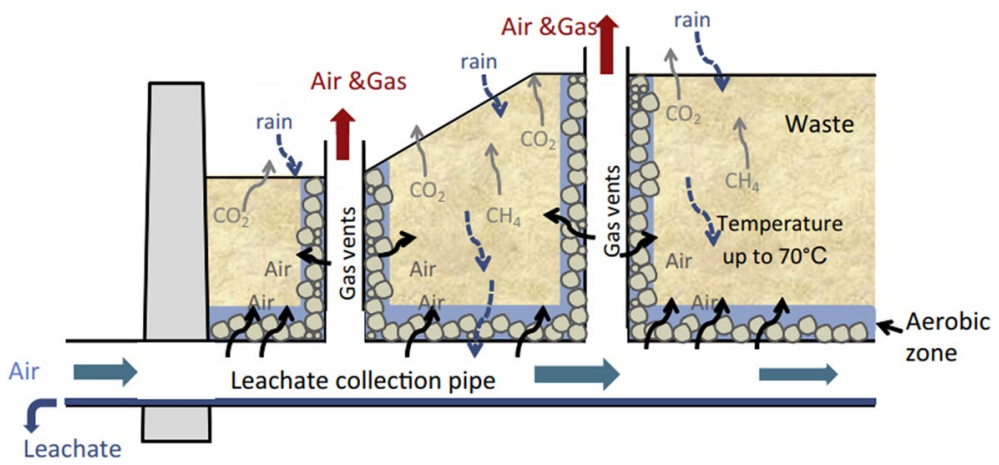

Fig. 7 Fukuoka method to capture leachate in second seventh landfill (Matsuto et al. 2015) 
Moreover, the logistics and transportation system centred in LC is also a major sector (Doaemo et al. 2020a, b; Sultan et al. 2019). Thus, this Province is a strategic territory with a huge potential in the development of the country and is the gateway to five highlands provinces in the country as well as Madang and the island Provinces (Fig. 8). The capital of MP is Lae City (LC) and it is the second-largest urban community of PNG, reaching over $100 \mathrm{~km}^{2}$ in the area, with an estimated population of 148,934 ("Districts of Papua New Guinea" 2014). Within LC there are two large communities, Ahi Local Level Government with a population of 60,326, and Lae Urban Local Level Government with a population of 88,608 . Nonetheless, its population is threatened by poverty (Cammack 2007), inequality (Johnson 1993), and diseases (Allen 1999) caused by the mismanagement of municipal solid waste (MSW) (Faried et al. 2020; Moses et al. 2020; Rungwa et al. 2013).

MSW, generally known as garbage or trash, consists of everyday items we use and then throw away, such as clothing, product packaging, furniture, bottles, grass clippings, newspapers, appliances, food scraps, paint, batteries, etc. Increasingly affluent lifestyles and continued industrial and commercial growth in LC in the past decade have been accompanied by rapid MSW production increment (Renou et al. 2008). It has been found that PNG's per capita household MSW generation rate is around $0.45 \mathrm{~kg}$ per person per day (Woodruff 2014). In Port Moresby, LC, and other populated cities, MSW generation rates are likely higher due to the migration of people that live in settlements (Woodruff 2014). Collection, management, and disposal of the MSW in the urban areas are challenges. Lack of MSW management and disposal is leading to significant environmental problems. This includes groundwater contamination due to leaching of waste dump (Abd El-Salam and Abu-Zuid 2015), surface water contamination due to run-off on the waste dump (Naveen et al. 2018), bad odour (Sarkar and Hobbs 2002), rodents (Duh et al. 2017), generation of inflammable gas such as methane within the waste dump (Noma et al. 2012), frequent fires (Ibrahim et al. 2017), the spread of epidemics due to stray animals (Mikalsen et al. 2020), and soil acidity (Domínguez et al. 2019).

As in many emerging countries, the selected method in LC to manage solid waste is to pile up the waste in an open space and burn it down (Cheng et al. 2020; Das et al. 2018; Alves et al. 2019). The LC has two main landfills, as shown in Fig. 9: the second seventh landfill (SSL), which is a 40-year-old MSW dumpsite, and the new Poasung landfill (PL). PL (Fig. 9) is close to the Busu River (a major natural water body in the region) and is managed by the local landowners. Many companies are avoiding tax or pay less to dispose of it in PL. SSL, however, is managed by the local government and funded through several taxes. SSL's budget is only a few percentage points of City Council revenue. According to the Development Policy Center, by 2012, the SSL's annual budget was 0.5 million PGK (US\$148,250.06). SSL is located near the Papua Guinea University of Technology (PNGUOT), and water supply station (Water PNG LTD), the primary water supplier with seven $30 \mathrm{~m}$ deep boreholes located $100 \mathrm{~m}$ from the SSL. In both SSL and PL, the waste is combusted in an open space with significant implications for residents of LC and the environment (Agarwal et al. 2020; Ahmed et al. 2019; Shakya et al. 2008). PNG, being a tropical country, receives annual precipitation of $4313 \mathrm{~mm}$, and its average temperature is about $24.6{ }^{\circ} \mathrm{C}$. Moreover, there is no infrastructure for leachate capture or treatment present in the SSL or the PL. Its design in this climate results in leachate contamination of the surrounding area and the water bodies. This is particularly concerning as the nearby Busu River, and its tributaries are primary drinking water for much of the population living in the Bumayong and Yanga area (Bhatt et al. 2017). In addition to this, there is no waste segregation at the source nor at the final destination, which makes it difficult for the recycling and the proper treatment as per the type of waste (Fig. 10). 


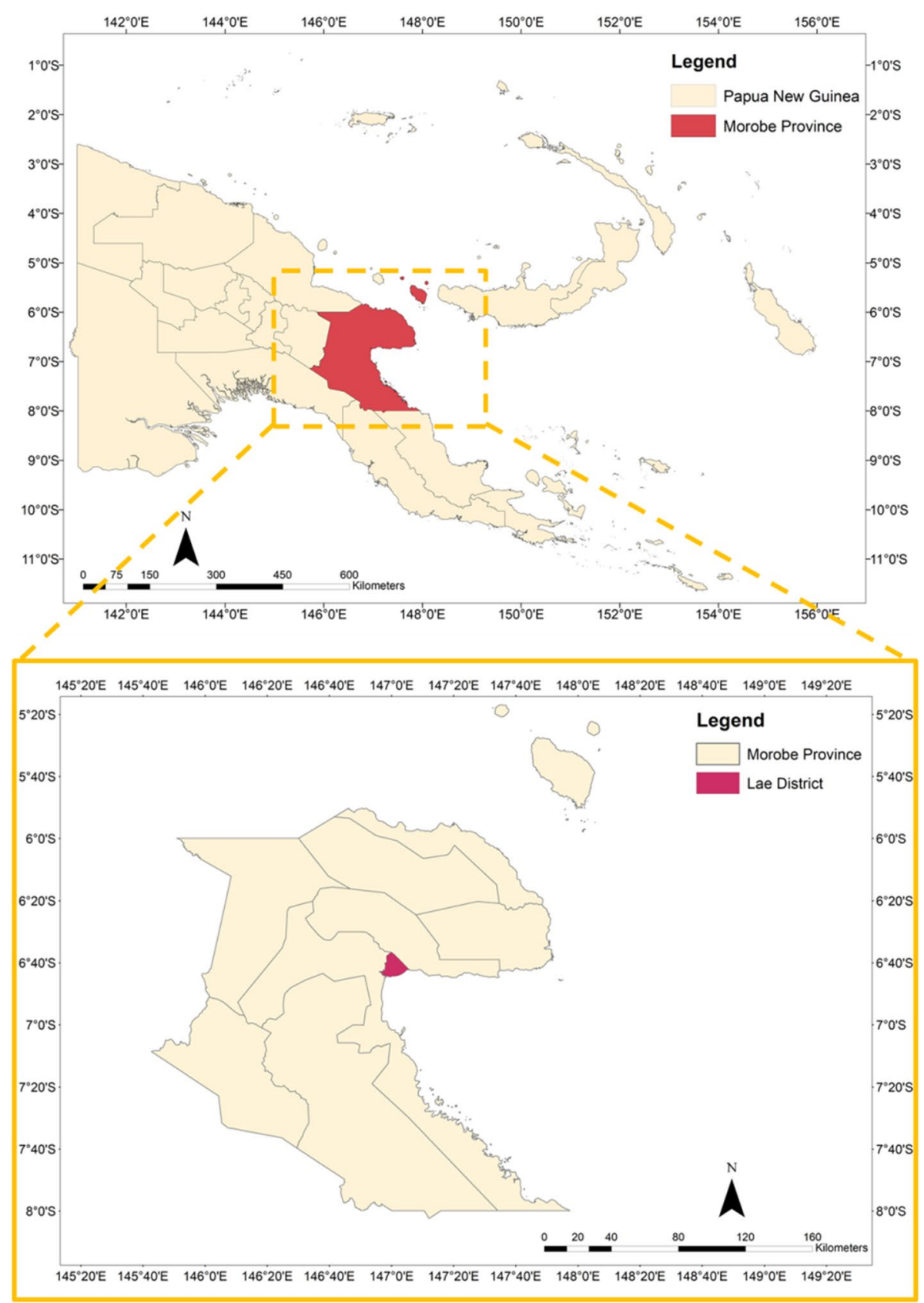

Fig. 8 Maps showing Morobe province and Lae district of Papua New Guinea

Morobe has 367 aid posts and 52 health centres in nine districts, but none have treatment infrastructure for the resulting medical and hazardous waste. With the outbreak of COVID-19 globally, medical waste generation will rise which puts increased 


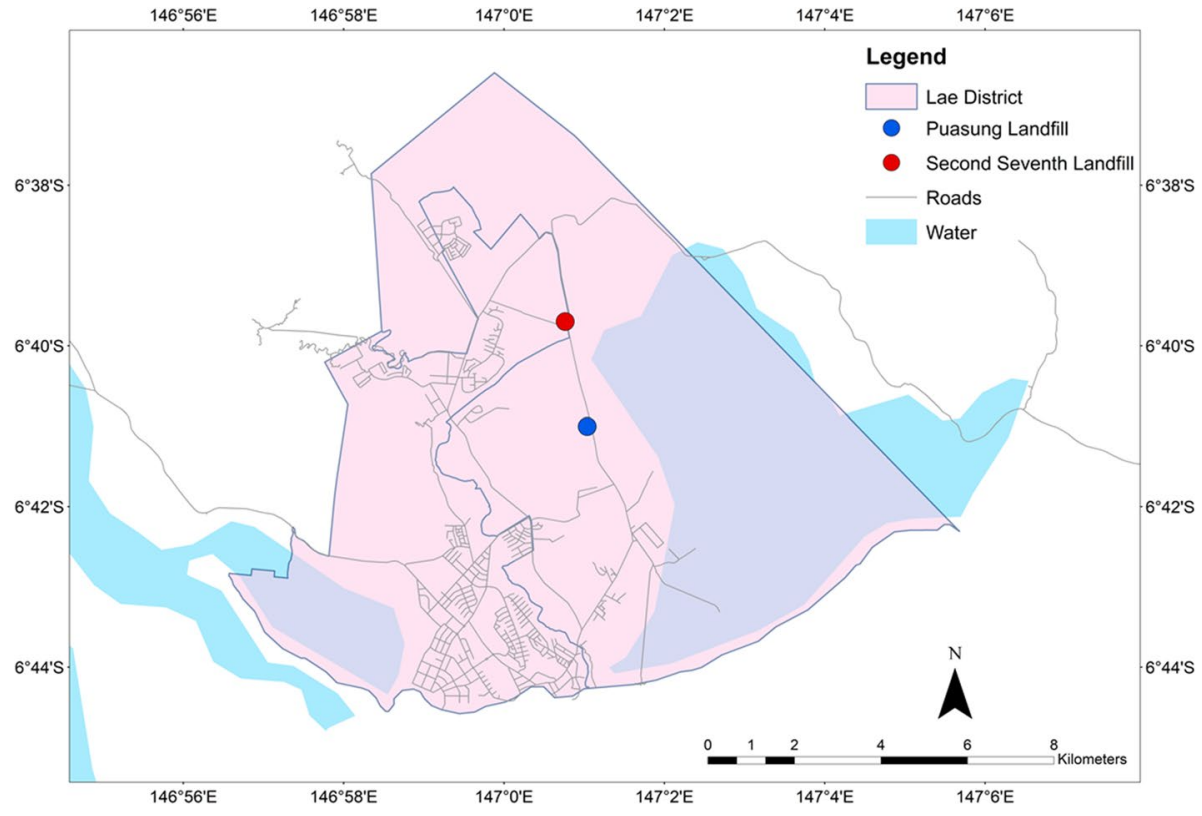

Fig. 9 Locations of the second seventh and Poasung landfills

Fig. 10 Issues with the current municipal solid waste management system

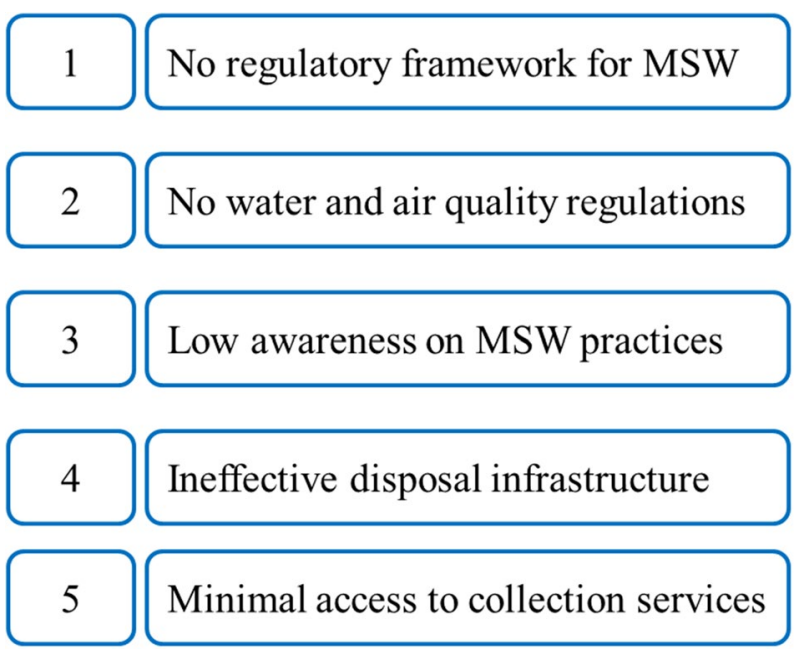

importance on adequate treatment and decontamination capabilities (Saadat et al. 2020). These materials currently are disposed of at SSL and Poasung dumpsite for treatment with all other types of solid waste. The resultant landfill gas is produced by the anaerobic degradation of organic material from various sources present in solid waste mainly composed of methane and carbon dioxide, and it may also contain a low amount of other toxic gases associated with decomposition including hydrogen sulphide, ammonia, 
hydrogen, and carbon monoxide. These are the issues concerning public health and the environment that need to be addressed and managed appropriately.

Many studies concerning the sustainable MSW management of developing cities have been undertaken by various authors such as solid waste characterization and quantification of Nigeria city was performed using ASTM D5231-92 method and the barriers against effective MSW management and recommendations for integrated MSW management strategies to include solid waste generation reduction, recycling, reuse, composting, and proper training and provision of incentive and other fiscal policies (Ugwu et al. 2020). Similarly, the complete evaluation resulted from an integrated MSW management strategy in Turkey in the development of strategies (behavioural, structural, and managerial) to decrease the solid waste generation rate, increase the recyclable material collection rate, and initiate compost activities (Berkun et al. 2011). The current studies do not address a consistent channel/pathway for the complete or integrated management of MSW. This study will leverage the existing work undertaken to develop an integrated approach that can be used as a valuable resource in designing a holistic waste management solution. Moreover in LC, due to the unavailability of skilled labour and resources, it is important to suggest a pathway for MSW management in a sustainable way. Thus, as a city that is seeing a significant increase in industrial development, it is imperative to review the existing system and establish a sustainable solid waste management system considering an integrated approach.

\section{Discussion}

LC, as the industrial heart of PNG, is full of opportunities to overcome the challenges ahead. To continue growth and development, it is mandatory to take care of the basic needs of its population. LC addresses several environmental regulations that dictate the responsibilities, powers, and functions of the institutions in charge of the protection of the environment. The institution in charge of noise control, litter, hygiene, and sanitation is the Provincial Environmental Council and the local level governments ruled by organic law on Provincial Governments and Local Level Governments. Nonetheless, there is no regulatory or enforcement framework for solid waste management in PNG. Despite all of the problems related to MSW in LC, there are many opportunities and advantages that must be considered and harnessed to develop a proper rehabilitation plan. With an increase in population and improvement in the quality of living, the amount of MSW is expected to rise largely in the PNG in the upcoming years. The province and its communities should set priorities for the efficient management of MSW in alignment with the waste management hierarchy. Efforts should be targeted at avoiding or reducing the waste generated by households and industries, followed by strategies to reduce, recycle, and recover resources and finally treat and dispose of.

The Universities in PNG have a leading role in the rehabilitation, not just to provide technical assistance, but also to create campaigns and raise awareness among the people of LC. The community's approach to the landfill and their relationship with their waste is the most important. Likewise, in Managua, and Nicaragua, several international cooperation projects have focused on the improvement of waste management systems creating multistakeholder platforms, designing and implementing joint activities for improving technical capacity and awareness, and boosting the implementation of integrated and appropriated projects (Olley 2014). In PNG, the government has sought to prohibit the import and use of plastic bags in order to prevent the production and accumulation of plastic waste. A 
decision by the court in favour of two major producers of plastic bags-Colorpak Ltd and W.H. Ltd Industries. Colorpak Ltd claimed that a plastic bag ban would result in the closure of their business, job losses, and argued that the proposed ban violated investment laws as stated by the constitution (SPREP 2010). This highlights the challenges of balancing sustainability and a functioning economy that provides jobs for the community.

In Vanuatu, a program of waste characterization coupled with education and capacity building was undertaken in Port Vila. By collecting and segregating waste from several areas which represent different socioeconomic groups, the team was able to determine the household generation rate, the composition, and the density of waste disposed to landfill. This also acts to build local knowledge and skills in decision-making, developing policies, and strategies for waste minimization in Vanuatu (Rovo 2011). Likewise, the solid waste production rate in Malaysia had increased significantly in recent years, ranging from 0.8 to $1.25 \mathrm{~kg} /$ person $\bullet$. The waste generated contains a high amount of organic portion with high moisture content and showed a reduction of $27 \%$ of greenhouse gases (GHG) by diverting the food and vegetable wastes from open dumping to the composting plant. A higher reduction rate $(\sim 44 \%)$ can be achieved with better planning of waste collection routes and applying the diversion strategies during waste processing (Lim et al. 2019). Gampaha Municipal Council of Sri Lanka had launched a pilot project on home composting, and the result shows that the waste generated was reduced by 69\% (Lekammudiyanse et al. 2009). Successful practices in several European countries suggest that source-separated composting presents many advantages over mechanical-separated composting. This may partially be ascribed to the fact that source separation of organic waste can prevent contact with heavy metal-bearing items, resulting in the production of high-quality compost. Mixed collection solid waste normally contains significantly higher concentrations of heavy metals, which could affect the marketing of composting products. Moreover, source separation of organic waste can minimize waste pre-treatment operations, leading to lower bio aerosol and malodor generation during composting. Standards must be set for end-product quality control and highly recommended to control both marketing and environmental risks (Wei et al. 2017).

In Campinas, the third-largest city in São Paulo with a population of over one million, the treatment of solid waste has been a serious problem since 2014. In this scenario, a selective collection index of $20 \%$ is adopted and the rest of MSW is incinerated with energy recovery. Results show that incineration can generate electrical energy sufficient for 135,680 homes and can render about US\$ $5.799 \times 106$ per month. The benefits from the selective collection index of $20 \%$ of the potentially available recyclables include a financial return of about US\$ 302,412 per month equivalent to 1120 national minimum salary, energy savings equivalent to $69.4 \mathrm{MW}$, and avoided emissions of about $145.77 \mathrm{ktCO} 2 /$ year equivalents to $6.2 \%$ of the total emissions of Campinas (Lino and Ismail 2017). Another important consideration of incineration is that incineration fly ash is a significant source of heavy metal pollution in the country. Incineration fly ash is largely mismanaged, posing a significant environmental risk. The development of proper stabilization and reuse technologies for fly ash is needed (Wang et al. 2019).

For the landfill itself, it can be observed from Fig. 11 that the scenario of SSL has changed drastically from 2002 to 2020 . It can be observed that the area dedicated to landfills has been occupied by the MSW from 2002 to 2020. Since LC receives high precipitation of more than $4313 \mathrm{~mm}$ annually, the leachate coming out of the solid organic waste at SSL is high and due to the anaerobic reaction, more methane will be liberated. In this anaerobic condition, solid waste decomposition will be very slow with excessive methane being released into the environment which can significantly 

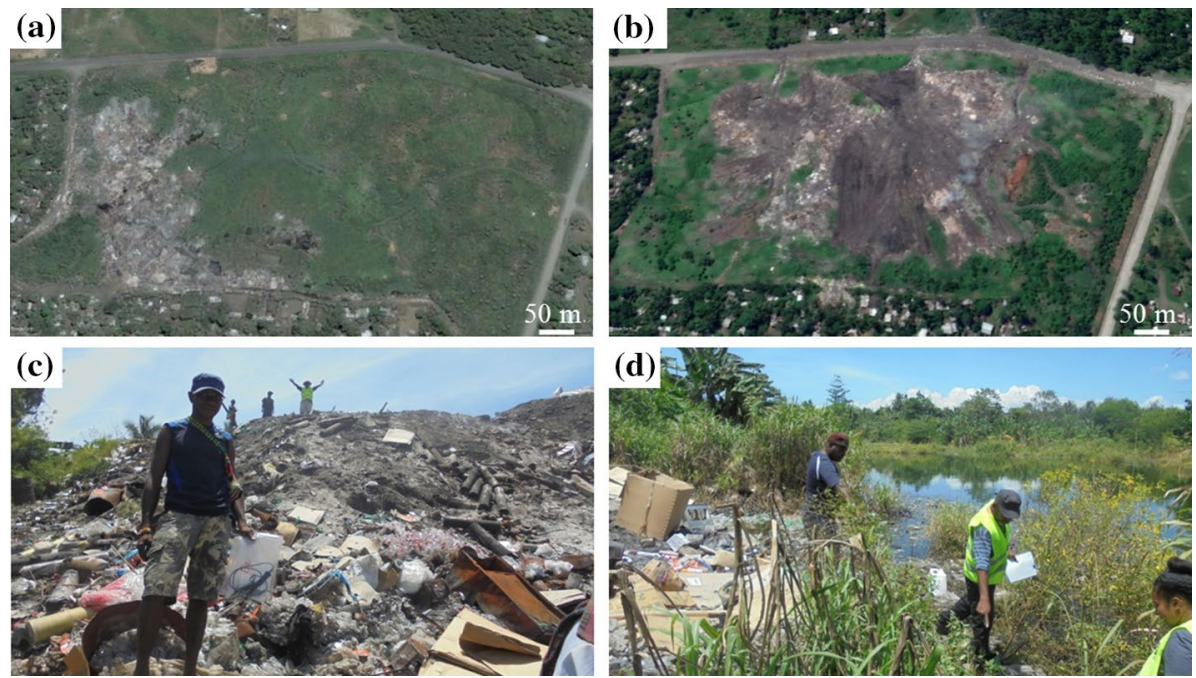

Fig. 11 a, b Geographical evolution of second seventh landfill over the years from 2002 to 2020; c, d ground-level investigation of waste composition

contribute to global warming. The appropriate action needed now at the SSL is to introduce air (oxygen) into the organic waste matter to allow for decomposition to take place. Using the Fukuoka method which is a semi-aerobic practiced initiated by the Japanese is recommended by the Secretariat Pacific Regional Programme for the Environment (SPREP), a body that is mandated to take action on waste management and the control of pollution. Furthermore, the characterization of landfill leachate was performed in Asia, Africa, and Latin America, and it was found that three heavy metals, viz. $\mathrm{Ni}, \mathrm{Cr}$, and $\mathrm{Zn}$, were significantly present at dumpsites. It was found that the concentrations of pollutants from sites are influenced mainly by local conditions, consumption patterns, and waste management habits of individuals. Thus, properly engineered landfill sites effectively reduce the risk associated with these pollutants (Vaccari et al. 2019). In 2008, the upgrade of the Tofol dumpsite located in Kosrae State to a semi-aerobic (Fukuoka-type) landfill was completed by the Federated States of Micronesia (FSM). The conversion to a semi-aerobic landfill began in February 2006 (took almost $2 \frac{1}{2}$ years to complete) with funding provided by the Embassy of Japan in Pohnpei through Grass-roots grant assistance (US\$90,900) and the Kosrae State Government (US\$36,100). As a result, in its four municipalities, Kosrae State has a sanitary facility to deal with waste disposal. Similar rehabilitation work took place at the M-Dock site in Palau, in Vanuatu and Samoa (SPREP 2010).

The little influence that solid waste managers in government and industry have over production decisions that impact waste generation, due to the absence of legislation, is an obstacle to enforcing the proposed 3CWMHS. Instead of waste recovery and reuse, the intense emphasis on preventive methods is increasingly known globally. Most of the current effort is still on recycling programs, which are important but not as effective as prevention or reduction strategies in achieving sustainability (Domínguez et al. 2019). 


\section{Policy and managerial implications}

This section aims to ensure that an apt policy framework goes hand in hand with actions that would enable the management of household waste in the sprawling urban population of LC, PNG. Provisions have been made to take into account the socio-economic and political boundary conditions of the Morobe Province. Therefore, the paper details actionable insights that can be implemented in the near future with the resources. If additional resources or stakeholder involvement is required, the same has been elucidated under the subsections. The desired behavioural change as a result of these policies will fall in one or more of three groups-efficiency, reduction, and substitution. For purposes of scoping, the paper will focus on policies in waste management that cater to consumables only. The paper will not address durable goods as that would be beyond the focus area of composting. In this section, we will address all levels of government—national, local, and regional.

\subsection{Under economic instruments, three solutions are addressed, namely deposit schemes for plastic containers, product pricing, and flexible fee on waste}

It is widely known that compost quality depends on sorting, but the proliferation of singleuse throwaway plastics negates efforts to responsibly compost household waste. Adopting this best practice from Sweden, the consumer pays a fee when purchasing the beverage, which is then returned if and when the container is deposited for recycling. The containers can be either plastic or metal. Moreover, it will be illegal for companies to sell containers that are not part of this authorized container deposit system, thereby ensuring higher rates of recycling (Moberg et al. 2019). These scheme's two core requirements are a high enough exchange rate to encourage deposits and infrastructure with container collection centres in every district. The exchange rate needs to be finalized by the necessitated corporations, the national government, and a local government such that the cost is not too high to discourage sales for the companies and at the same time, is not too low to discredit the deposit system. Substantial levels of funding will be required to establish new recycling centres but existing recycling centres need only be repurposed. By improving the availability of return points for recycling glass, metal, and other materials, the Lae city authority can improve its sorting operations. If all households were required to use the waste collection infrastructure and would be taxed proportionate to the quantity of waste disposed of, the Lae city authority would have a total monopoly over waste management systems (CBCNY 2015).

Higher pricing of virgin plastics can reduce the volume of waste disposed of. The price dynamic between recycled plastic and virgin plastic must be controlled. Currently, recycled plastic is not price competitive to virgin plastic but in case of a shortage of virgin plastic as in China, the price of recycled plastic will increase and in the longer term, will result in incentives for improved waste collection and sorting which may result in fewer plastics dispersion (OECD 2018). Additionally, since most consumer purchases are dictated by cost, product pricing must be controlled in such a way that renewable resources that can serve as substitutes for traditional non-renewable resources must be priced lower.

A flexible fee on waste ensures that households dispose less and recycle more since the fee is relative to waste volume (Moberg et al. 2019). Customers good at recycling waste (plastic, paper, other containers) and dispose of less are rewarded by paying a smaller fee for LC authority. In the near term, LC can start with a trial arrangement to resolve some of the challenges to such a system. One such challenge is to develop a good system for those 
living in building blocks with shared waste collection points. This measure would also decrease the disposal rates of one-time-use products which would dramatically decrease waste generated.

\subsection{Under regulatory approaches, three regulations are explained, namely prohibitions, taxation of products, and eco-labelling}

A national ban on single-use plastic, be it total or partial, will be most effective in reducing the proportion of plastic accumulated in household waste (OECD 2018). However, lobbying efforts will be required to pass such legislation (Guo 2015). One-time use products should be taxed according to their environmental footprint after a thorough life-cycle analysis (Timmermans and Achten 2018). According to ADEME, the national agency for the environment, energy, and waste in France, each French citizen could lower his/her generation of waste by $150 \mathrm{~kg}$ per year through compost, less wasting, lowering the consumption of paper, and better sorting of waste. Hence, the potential to reduce waste is significant (Moberg et al. 2019).

Sometimes it is not known if a product is compostable or not. For example, meat should not be composted but it is often perceived as being compostable (Walker 1996). Hence, the national government must issue a national eco-labelling system that categorizes products according to the degree of recyclability with appropriate and easy-to-understand labels. This will prove to be a catalyst, especially for compostable waste. The labels can also direct consumers on how to compost/dispose of that particular product. The successful implementation of such a label depends on advertising and consumer awareness campaigns (Naumann 2015). The government must ensure that the governing official environmental labels adhere to ISO 14,024 environmental label and declaration standards ("ISO 14,024:2018" 2018). Along a similar line, the governing foundation must also set benchmarking tools for companies so that they can assess and reduce their environmental impact.

\subsection{Under informational policies, three mechanisms are delineated, namely information campaigns, community leadership, and suasion}

These policies are predominantly educational. For example, schools must teach composting from a young age because the habits then inculcated will be carried forward when they become independent purchasers. A second example would be teaching small businesses to incorporate circular economy as a central feature to reduce the amount of waste going to landfills and achieve 100\% plastic recycling ("THE CIRCULAR ECONOMY" 2017). The government must appoint regional 'Climate Ambassadors' with a history of having contributed to advancing climate issues (Moberg et al. 2019). These Climate Ambassadors will be expected to lead by example and work to increase knowledge of, and attention to, climate issues among citizens. Regional climate ambassadors can coordinate to further national climate goals. On a grassroots level, they can be entrusted with the responsibility to train denizens including teachers at schools, landfill management personnel, and small businesses on important topics such as sorting and recycling waste and reading eco-labels correctly.

Adopting best practices from European countries, PNG's strategy for sustainable development must focus on setting goals to increase the sales volumes of products that have an eco-label (Moberg et al. 2019). The same can be sped up if major distribution firms of PNG such as supermarket retailers classify the products they sell according to different 
categories under the labelling system. The aforementioned measure would not only provide the consumer with necessary information for choosing environmentally sound and informed products, but would also prevent the proliferation of false self-proclaimed labels by corporations. The governing foundation set-up to supervise the label must investigate false environmental claims which occur more often in marketing campaigns in an effort to greenwash consumers (Moberg et al. 2019).

The basis of intelligent and effective policies is a well-funded research ecosystem. Hence, reputed academicians from multiple disciplines must quantify the cost reductions in waste management from the above actions to prove to governing officials and relevant stakeholders that these actions are not only socially responsible but also have a payback period with the opportunity for cost savings and energy generation. Additionally, upon research, the financial responsibilities of industries must be adjusted according to their environmental impact.

\section{Conclusions}

The present research assessed opportunities and challenges associated with the current MSW management system in Lae city of Papua New Guinea based on the 3 core waste management hierarchy, which separated waste solutions into three categories, namely waste avoidance, resource recovery, and disposal. After studying various aspects based on the availability of resources, existing policies, and lack of technological advancement, it can be put forward that waste avoidance in LC can be achieved through community education campaigns and waste characterization initiatives such as source separation (Kumar and Agrawal 2020) supported by policies aligned with sustainable waste management practices. For reuse and recycling in LC, the most significant opportunity is the adoption of composting processes on a residential, community, and industrial scale, considering the composition is mainly organics. On the residential and community level, vermicomposting is suggested as a sustainable, economically viable, and easy method to stabilize organic waste without any adverse effects to the environment or human health (Pirsaheb et al. 2013). On the Industrial level, aerated static pile composting is suggested as a promising method in LC due to the less availability of sophisticated instruments and skilled labour (Luo et al. 2008). These practices would result in large volumes of waste being reused and diverted from landfills. Besides, incineration is a potential answer for energy and electricity recovery from the leftover (treated and dried organic fraction of MSW) and non-organic waste, whereas it requires significant investment for infrastructure and ongoing operations. Responsible and sustainable management of ash generated from this process is critical to minimize negative impacts. To achieve this, fly ash is recommended for use in building materials such as hybrid cement (Zhang et al. 2020). Disposal is inevitable in the waste management process. The Fukuoka method offers a promising solution for the remediation of the second seventh landfill (SSL) by capturing leachate and methane recovery. This approach has proven successful in emerging nations with similar landfills due to its simplicity and low costs, which lowers the barrier to its implementation (Amiri et al. 2016). Nonetheless, all stakeholders including waste generators, politicians, and MSW control service providers must work together in policy formulation to improve MSW management in LC (Iyamu et al. 2020).

Acknowledgements The authors are grateful to the United Nations Volunteering program (https://www. onlinevolunteering.org/en) as well as to the following people for their contribution with reviewing and 
editing the draft versions of the manuscript: Mikey Mid Mohan (Department of Geography, University of California, Berkeley) and Lenka Kollar (Co-founder of Helixos, Australia). We would also like to thank the anonymous reviewers.

Authors' contribution Willie Doaemo was involved in writing — original draft preparation, writing-reviewing and editing, resources, project administration, Sahil Dhiman helped in conceptualization, methodology, writing-original draft preparation, writing-reviewing and editing. Alexander Borovskis contributed in writing-original draft preparation, writing-reviewing and editing. Wenlan Zhang was involved in writing-reviewing and editing. Sumedha Bhat helped in writing - reviewing and editing, supervision. Srishti Jaipuria contributed to software. Mirzi Betasolo helped in Supervision. All authors have read and agreed to the published version of the manuscript.

Funding This research did not receive any specific grant from funding agencies in the public, commercial, or not-for-profit sectors.

\section{Declarations}

Competing interest The authors declare that they have no known competing financial interests or personal relationships that could have appeared to influence the work reported in this paper.

\section{References}

Abad, V., Avila, R., Vicent, T., \& Font, X. (2019). Promoting circular economy in the surroundings of an organic fraction of municipal solid waste anaerobic digestion treatment plant: Biogas production impact and economic factors. Bioresource Technology, 283, 10-17. https://doi.org/https://doi.org/10. 1016/j.biortech.2019.03.064

Abd El-Salam, M. M., \& I. Abu-Zuid, G. (2015). Impact of landfill leachate on the groundwater quality: A case study in Egypt. Journal of Advanced Research, 6(4), 579-586. https://doi.org/https://doi.org/10. 1016/j.jare.2014.02.003

Adam, M. G., Tran, P. T. M., Bolan, N., \& Balasubramanian, R. (2021). Biomass burning-derived airborne particulate matter in Southeast Asia: A critical review. Journal of Hazardous Materials, 407, 124760. https://doi.org/https://doi.org/10.1016/j.jhazmat.2020.124760

Adelodun, B., Kim, S. H., \& Choi, K.-S. (2021). Assessment of food waste generation and composition among Korean households using novel sampling and statistical approaches. Waste Management, 122, 71-80. https://doi.org/https://doi.org/10.1016/j.wasman.2021.01.003

Agapios, A., Andreas, V., Marinos, S., Katerina, M., \& Antonis, Z. A. (2020). Waste aroma profile in the framework of food waste management through household composting. Journal of Cleaner Production, 257, 120340. https://doi.org/https://doi.org/10.1016/j.jclepro.2020.120340

Agarwal, R., Shukla, K., Kumar, S., Aggarwal, S. G., \& Kawamura, K. (2020). Chemical composition of waste burning organic aerosols at landfill and urban sites in Delhi. Atmospheric Pollution Research, 11(3), 554-565. https://doi.org/https://doi.org/10.1016/j.apr.2019.12.004

Ahmed, O. Y., Ries, M. J., \& Northrop, W. F. (2019). Emissions factors from distributed, small-scale biomass gasification power generation: Comparison to open burning and large-scale biomass power generation. Atmospheric Environment, 200, 221-227. https://doi.org/https://doi.org/10.1016/j.atmosenv. 2018.12.024

Alidadi, H., Hosseinzadeh, A., Najafpoor, A. A., Esmaili, H., Zanganeh, J., Dolatabadi Takabi, M., \& Piranloo, F. G. (2016). Waste recycling by vermicomposting: Maturity and quality assessment via dehydrogenase enzyme activity, lignin, water soluble carbon, nitrogen, phosphorous and other indicators. Journal of Environmental Management, 182, 134-140. https://doi.org/https://doi.org/10.1016/j.jenvm an.2016.07.025

Allen, B. (1999). Rural poverty in Papua New Guinea. Development Bulletin - Australian Development Studies Network, 49, 42-44

Alves, C. A., Vicente, E. D., Evtyugina, M., Vicente, A., Pio, C., Amado, M. F., \& Mahía, P. L. (2019). Gaseous and speciated particulate emissions from the open burning of wastes from tree pruning. Atmospheric Research, 226, 110-121. https://doi.org/https://doi.org/10.1016/j.atmosres.2019.04.014

Amiri, A. W., Tsutsumi, J. G., \& Nakamatsu, R. (2016). A Case Study of Fukuoka Landfill Method and Environmental Impact Assessment of Solid Waste Management in Kabul City, 4(4), 46-51. 
Arantes, V., Zou, C., \& Che, Y. (2020). Coping with waste: A government-NGO collaborative governance approach in Shanghai. Journal of Environmental Management, 259, 109653. https://doi.org/https:// doi.org/10.1016/j.jenvman.2019.109653

Asensio, V., Abreu-Junior, C. H., da Silva, F. C., \& Chitolina, J. C. (2018). Evaluation of chemical extractants to assess metals phytoavailability in Brazilian municipal solid waste composts. Environmental Pollution, 243, 1235-1241. https://doi.org/https://doi.org/10.1016/j.envpol.2018.09.100

Azevedo, B. D., Scavarda, L. F., Caiado, R. G. G., \& Fuss, M. (2021). Improving urban household solid waste management in developing countries based on the German experience. Waste Management, 120, 772-783. https://doi.org/https://doi.org/10.1016/j.wasman.2020.11.001

Behrooznia, L., Sharifi, M., Alimardani, R., \& Mousavi-Avval, S. H. (2018). Sustainability analysis of landfilling and composting-landfilling for municipal solid waste management in the north of Iran. Journal of Cleaner Production, 203, 1028-1038. https://doi.org/https://doi.org/10.1016/j.jclepro.2018.08.307

Berkun, M., Aras, E., \& Anılan, T. (2011). Solid waste management practices in Turkey. Journal of Material Cycles and Waste Management, 13(4), 305-313. https://doi.org/10.1007/s10163-011-0028-7

Bernstad, A, \& la Cour Jansen, J. (2012). Separate collection of household food waste for anaerobic degradation: Comparison of different techniques from a systems perspective. Waste Management, 32(5), 806-815. https://doi.org/https://doi.org/10.1016/j.wasman.2012.01.008

Bernstad, A., la Cour Jansen, J., \& Aspegren, H. (2011). Life cycle assessment of a household solid waste source separation programme: A Swedish case study. Waste Management \& Research, 29(10), 10271042. https://doi.org/10.1177/0734242X11406170

Bhatt, A. H., Karanjekar, R. V, Altouqi, S., Sattler, M. L., Hossain, M. D. S., \& Chen, V. P. (2017). Estimating landfill leachate BOD and COD based on rainfall, ambient temperature, and waste composition: Exploration of a MARS statistical approach. Environmental Technology \& Innovation, 8, 1-16. https://doi.org/https://doi.org/10.1016/j.eti.2017.03.003

Bhattacharya, S. S., Kim, K.-H., Ullah, M. A., Goswami, L., Sahariah, B., Bhattacharyya, P., et al. (2016). The effects of composting approaches on the emissions of anthropogenic volatile organic compounds: A comparison between vermicomposting and general aerobic composting. Environmental Pollution, 208, 600-607. https://doi.org/https://doi.org/10.1016/j.envpol.2015.10.034

Bortoleto, A. P., Kurisu, K. H., \& Hanaki, K. (2012). Model development for household waste prevention behaviour. Waste Management, 32(12), 2195-2207. https://doi.org/https://doi.org/10.1016/j.wasman. 2012.05.037

Bulkeley, H., \& Gregson, N. (2009). Crossing the threshold: Municipal waste policy and household waste generation. Environment and Planning A: Economy and Space, 41(4), 929-945. https://doi.org/10. 1068/a40261

Cai, J., Zheng, W., Luo, M., \& Tang, X. (2021). Gasification of biomass waste in the moving-grate gasifier with the addition of all air into the oxidizing stage: Experimental and numerical investigation. Process Safety and Environmental Protection, 147, 985-992. https://doi.org/https://doi.org/10.1016/j. psep.2021.01.022

Cammack, D. (2007). Chronic poverty in Papua New Guinea. SSRN Electronic Journal. https://doi.org/10. 2139/ssrn. 1755079

Casazza, M., Huisingh, D., Ulgiati, S., Severino, V., Liu, G., \& Lega, M. (2019). Product service systembased municipal solid waste circular management platform in Campania Region (Italy): a preliminary analysis. Procedia CIRP, 83, 224-229. https://doi.org/https://doi.org/10.1016/j.procir.2019.03.085

CBCNY. (2015). A better way to pay for solid waste management. https://cbcny.org/research/better-waypay-solid-waste-management. Accessed 31 Jan 2021.

Chen, Y.-T., \& Chang, D.-S. (2010). Diffusion effect and learning effect: an examination on MSW recycling. Journal of Cleaner Production, 18(5), 496-503. https://doi.org/https://doi.org/10.1016/j.jclepro.2009. 12.013

Cheng, K., Hao, W., Wang, Y., Yi, P., Zhang, J., \& Ji, W. (2020). Understanding the emission pattern and source contribution of hazardous air pollutants from open burning of municipal solid waste in China. Environmental Pollution, 263, 114417. https://doi.org/https://doi.org/10.1016/j.envpol.2020.114417

Chung, S., \& Poon, C. (1999). The attitudes of Guangzhou citizens on waste reduction and environmental issues. Resources, Conservation and Recycling, 25(1), 35-59. https://doi.org/https://doi.org/10.1016/ S0921-3449(98)00057-3

Das, B., Bhave, P. V, Sapkota, A., \& Byanju, R. M. (2018). Estimating emissions from open burning of municipal solid waste in municipalities of Nepal. Waste Management, 79, 481-490. https://doi. org/https://doi.org/10.1016/j.wasman.2018.08.013

De Silva, S., \& Yatawara, M. (2017). Assessment of aeration procedures on windrow composting process efficiency: A case on municipal solid waste in Sri Lanka. Environmental Nanotechnology, Monitoring \& Management, 8, 169-174. https://doi.org/https://doi.org/10.1016/j.enmm.2017.07.008 
Dehkordi, S. M. M. N., Jahromi, A. R. T., Ferdowsi, A., Shumal, M., \& Dehnavi, A. (2020). Investigation of biogas production potential from mechanical separated municipal solid waste as an approach for developing countries (case study: Isfahan-Iran). Renewable and Sustainable Energy Reviews, 119, 109586. https://doi.org/https://doi.org/10.1016/j.rser.2019.109586

Districts of Papua New Guinea. (2014). http://www.statoids.com/ypg.html. Accessed 1 Aug 2020.

Doaemo, W., Mohan, M., Adrah, E., Srinivasan, S., \& Corte, A. (2020a). Exploring forest change spatial patterns in Papua New Guinea: A pilot study in the Bumbu River Basin. Land, 9, 282. https://doi.org/ $10.3390 /$ land9090282

Doaemo, W., Wuest, L., Bajaj, S., Shafrina, W., Jaafar, W. S. W. M., \& Mohan, M. (2020). Analytical protocol to estimate the relative importance of environmental and anthropogenic factors in influencing runoff quality in the Bumbu Watershed, Papua New Guinea. Hydrology, 7, 77. https://doi.org/https:// doi.org/10.3390/hydrology7040077

Domínguez, M., Paradelo Núñez, R., Piñeiro, J., \& Barral, M. T. (2019). Physicochemical and biochemical properties of an acid soil under potato culture amended with municipal solid waste compost. International Journal of Recycling of Organic Waste in Agriculture, 8(2), 171-178. https://doi.org/10.1007/ s40093-019-0246-X

Doña-Grimaldi, V. M., Palma, A., Ruiz-Montoya, M., Morales, E., \& Díaz, M. J. (2019). Energetic valorization of MSW compost valorization by selecting the maturity conditions. Journal of Environmental Management, 238, 153-158. https://doi.org/https://doi.org/10.1016/j.jenvman.2019.02.125

Duh, D., Hasic, S., \& Buzan, E. (2017). The impact of illegal waste sites on a transmission of zoonotic viruses. Virology journal, 14(1), 134. https://doi.org/10.1186/s12985-017-0798-1

Emmanuel, E., Anggraini, V., Raghunandan, M. E., \& Asadi, A. (2020). Utilization of marine clay as a bottom liner material in engineered landfills. Journal of Environmental Chemical Engineering, 8(4), 104048. https://doi.org/https://doi.org/10.1016/j.jece.2020.104048

Faried, A., Putra, S. P. S., Suradji, E. W., Trianto, Akbar, R. R., Nugraheni, N. K., \& Arifin, M. Z. (2020). Characteristics and outcomes of pediatric tuberculous meningitis patients with complicated by hydrocephalus with or without tuberculoma at Regional Public Hospital Teluk Bintuni, West Papua, Indonesia. Interdisciplinary Neurosurgery, 19, 100609. https://doi.org/https://doi.org/10.1016/j.inat.2019. 100609

Faverial, J., \& Sierra, J. (2014). Home composting of household biodegradable wastes under the tropical conditions of Guadeloupe (French Antilles). Journal of Cleaner Production, 83, 238-244. https://doi. org/https://doi.org/10.1016/j.jclepro.2014.07.068

Ferraz, F. M., \& Yuan, Q. (2020). Performance of oat hulls activated carbon for COD and color removal from landfill leachate. Journal of Water Process Engineering, 33, 101040. https://doi.org/https://doi. org/10.1016/j.jwpe.2019.101040

Ferronato, N., \& Torretta, V. (2019). Waste mismanagement in developing countries: A review of global issues. International Journal of Environmental Research and Public Health, 16(6). https://doi. org/https://doi.org/10.3390/ijerph16061060

Gertsakis, J., \& Lewis, H. (2003). Sustainability and the Waste Management Hierarchy. A discussion paper on the waste management hierarchy and its relationship to sustainability, (March), 16. http://www. ecorecycle.vic.gov.au/resources/documents/TZW_-_Sustainability_and_the_Waste_Hierarchy_ (2003).pdf

Ghosh, P., Kumar, M., Kapoor, R., Kumar, S. S., Singh, L., Vijay, V., et al. (2020). Enhanced biogas production from municipal solid waste via co-digestion with sewage sludge and metabolic pathway analysis. Bioresource Technology, 296, 122275. https://doi.org/https://doi.org/10.1016/j.biortech.2019.122275

Guo, J. (2015). A plastic bag lobby exists, and it's surprisingly tough. https:/www.washingtonpost.com/ blogs/govbeat/wp/2015/03/03/a-plastic-bag-lobby-exists-and-its-surprisingly-tough/. Accessed 31 Jan 2021

Halkos, G., \& Petrou, K. N. (2020). The relationship between MSW and education: WKC evidence from 25 OECD countries. Waste Management, 114, 240-252. https://doi.org/https://doi.org/10.1016/j.wasman.2020.06.044

He, P., Wei, S., Shao, L., \& Lü, F. (2019). Aerosolization behavior of prokaryotes and fungi during composting of vegetable waste. Waste Management, 89, 103-113. https://doi.org/https://doi.org/10.1016/j. wasman.2019.04.008

Heidari, R., Yazdanparast, R., \& Jabbarzadeh, A. (2019). Sustainable design of a municipal solid waste management system considering waste separators: A real-world application. Sustainable Cities and Society, 47, 101457. https://doi.org/https://doi.org/10.1016/j.scs.2019.101457

Hettiarachchi, H., Meegoda, J. N., \& Ryu, S. (2018). Organic waste buyback as a viable method to enhance sustainable municipal solid waste management in developing countries. International Journal of Environmental Research and Public Health, 15(11), 2483. https://doi.org/10.3390/ijerph15112483 
Hogland, W., \& Marques, M. (2010). Enhanced landfill mining: Material recovery, energy utilization and economics in the EU (Directive) perspective. In Enhanced landfill mining and the transition of sustainable materials management.: Proceedings of the international academic symposium on enhanced landfill mining, Houthalen-Helchteren, Belgium, (2016), 209-222. http://lnu.diva-portal.org/smash/ record.jsf?pid=diva2:426824

Hopewell, J., Dvorak, R., \& Kosior, E. (2009). Plastics recycling: challenges and opportunities. Philosophical transactions of the Royal Society of London. Series B, Biological sciences, 364(1526), 21152126. https://doi.org/https://doi.org/10.1098/rstb.2008.0311

Ibrahim, M., Hogland, W., Elmberg, E., Lönnermark, A., \& Person, H. (2017). Fires due to self-ignition in (MSWS) municipal solid waste storages. Linnaeus Eco-Tech, 734. https://doi.org/https://doi.org/10. 15626/Eco-Tech.2010.080

ISO 14024:2018. (2018). https://www.iso.org/standard/72458.html. Accessed 31 Jan 2021.

Iyamu, H. O., Anda, M., \& Ho, G. (2020). A review of municipal solid waste management in the BRIC and high-income countries: A thematic framework for low-income countries. Habitat International, 95, 102097. https://doi.org/https://doi.org/10.1016/j.habitatint.2019.102097

Johnson, P. (1993). Education and the "new" inequality in Papua New Guinea. Anthropology \& Education Quarterly, 24, 183-204. https://doi.org/10.1525/aeq.1993.24.3.05x0967e

Kalambura, S., Racz, A., \& Kalambura, D. (2015). Education in waste management. In Proceedings of the WasteSafe 2015 - 4th international conference on solid waste management in the developing countries (pp. 1-9).

Kale, C., \& Gökçek, M. (2020). A techno-economic assessment of landfill gas emissions and energy recovery potential of different landfill areas in Turkey. Journal of Cleaner Production, 275, 122946. https:// doi.org/https://doi.org/10.1016/j.jclepro.2020.122946

Keng, Z. X., Chong, S., Ng, C. G., Ridzuan, N. I., Hanson, S., Pan, G.-T., et al. (2020). Community-scale composting for food waste: A life-cycle assessment-supported case study. Journal of Cleaner Production, 261, 121220. https://doi.org/https://doi.org/10.1016/j.jclepro.2020.121220

Kerf, M., Panzer, J., Diop, N., \& Veevers, P. (2019). Slower growth, better prospects. World Bank Group. http://documents.worldbank.org/curated/en/597161549016416469/pdf/Papua-New-Guinea-Econo mic-Update-Slower-Growth-Better-Prospects.pdf

Kormi, T., Mhadhebi, S., Bel Hadj Ali, N., Abichou, T., \& Green, R. (2018). Estimation of fugitive landfill methane emissions using surface emission monitoring and Genetic Algorithms optimization. Waste Management, 72, 313-328. https://doi.org/https://doi.org/10.1016/j.wasman.2016.11.024

Kumar, Akhilesh, \& Agrawal, A. (2020). Recent trends in solid waste management status, challenges, and potential for the future Indian cities: A review. Current Research in Environmental Sustainability, 2, 100011. https://doi.org/https://doi.org/10.1016/j.crsust.2020.100011

Kumar, Atul, \& Samadder, S. R. (2017). A review on technological options of waste to energy for effective management of municipal solid waste. Waste Management, 69, 407-422. https://doi.org/https://doi. org/10.1016/j.wasman.2017.08.046

Larson, S. L., Martin, W. A., Şengör, S. S., Wade, R., \& Altamimi, F. (2021). Amendment for increased methane production rate in municipal solid waste landfill gas collection systems. Science of The Total Environment, 772, 145574. https://doi.org/https://doi.org/10.1016/j.scitotenv.2021.145574

Lekammudiyanse, M., Gunatilake, S., \& Head. . (2009). Efficiency of the Household Compost bin as a Waste Management Technique in Sri Lanka (A Case Study in Gampaha Municipal Council Area). International Journal of Basic \& Applied Sciences, 10, 89

Lim, L. Y., Lee, C. T., Bong, C. P. C., Lim, J. S., \& Klemeš, J. J. (2019). Environmental and economic feasibility of an integrated community composting plant and organic farm in Malaysia. Journal of Environmental Management, 244, 431-439. https://doi.org/https://doi.org/10.1016/j.jenvman.2019.05.050

Lino, F. A. M., \& Ismail, K. A. R. (2017). Incineration and recycling for MSW treatment: Case study of Campinas, Brazil. Sustainable Cities and Society, 35, 752-757. https://doi.org/https://doi.org/10. 1016/j.scs.2017.09.028

Lo, H. M., Kurniawan, T. A., Sillanpää, M. E. T., Pai, T. Y., Chiang, C. F., Chao, K. P., et al. (2010). Modeling biogas production from organic fraction of MSW co-digested with MSWI ashes in anaerobic bioreactors. Bioresource Technology, 101(16), 6329-6335. https://doi.org/https://doi.org/10.1016/j. biortech.2010.03.048

Lohri, C. R., Camenzind, E. J., \& Zurbrügg, C. (2014). Financial sustainability in municipal solid waste management: Costs and revenues in Bahir Dar, Ethiopia. Waste Management, 34(2), 542-552. https:// doi.org/https://doi.org/10.1016/j.wasman.2013.10.014

Lou, Z., Wang, L., \& Zhao, Y. (2011). Consuming un-captured methane from landfill using aged refuse biocover. Bioresource Technology, 102(3), 2328-2332. https://doi.org/https://doi.org/10.1016/j.biortech. 2010.10.086 
Luo, W., Chen, T. B., Zheng, G. D., Gao, D., Zhang, Y. A., \& Gao, W. (2008). Effect of moisture adjustments on vertical temperature distribution during forced-aeration static-pile composting of sewage sludge. Resources, Conservation and Recycling, 52(4), 635-642. https://doi.org/https://doi.org/10. 1016/j.resconrec.2007.08.004

Madden, B., Florin, N., Mohr, S., \& Giurco, D. (2021). Spatial modelling of municipal waste generation: Deriving property lot estimates with limited data. Resources, Conservation and Recycling, 168, 105442. https://doi.org/https://doi.org/10.1016/j.resconrec.2021.105442

Magazzino, C., Mele, M., \& Schneider, N. (2020). The relationship between municipal solid waste and greenhouse gas emissions: Evidence from Switzerland. Waste Management, 113, 508-520. https:// doi.org/https://doi.org/10.1016/j.wasman.2020.05.033

Makan, A., Fadili, A., \& Oubenali, M. (2020). Interaction of physicochemical parameters during pressurized in-vessel composting of food waste. Bioresource Technology Reports, 10, 100350. https://doi. org/https://doi.org/10.1016/j.biteb.2019.100350

Matsuto, T., Zhang, X., Matsuo, T., \& Yamada, S. (2015). Onsite survey on the mechanism of passive aeration and air flow path in a semi-aerobic landfill. Waste Management, 36, 204-212. https://doi. org/https://doi.org/10.1016/j.wasman.2014.11.007

Mazzarano, M., De Jaeger, S., \& Rousseau, S. (2021). Non-constant income elasticities of waste generation. Journal of Cleaner Production, 297, 126611. https://doi.org/https://doi.org/10.1016/j.jclepro.2021. 126611

Michel Devadoss, P. S., Agamuthu, P., Mehran, S. B., Santha, C., \& Fauziah, S. H. (2021). Implications of municipal solid waste management on greenhouse gas emissions in Malaysia and the way forward. Waste Management, 119, 135-144. https://doi.org/https://doi.org/10.1016/j.wasman.2020.09.038

Mikalsen, R. F., Lönnermark, A., Glansberg, K., McNamee, M., \& Storesund, K. (2020). Fires in waste facilities: Challenges and solutions from a Scandinavian perspective. Fire Safety Journal, 103023. https://doi.org/https://doi.org/10.1016/j.firesaf.2020.103023

Moberg, K. R., Aall, C., Dorner, F., Reimerson, E., Ceron, J.-P., Sköld, B., et al. (2019). Mobility, food and housing: Responsibility, individual consumption and demand-side policies in European deep decarbonisation pathways. Energy Efficiency, 12(2), 497-519. https://doi.org/10.1007/s12053-018-9708-7

Montejo, C., Costa, C., \& Márquez, M. C. (2015). Influence of input material and operational performance on the physical and chemical properties of MSW compost. Journal of Environmental Management, 162, 240-249. https://doi.org/https://doi.org/10.1016/j.jenvman.2015.07.059

Moses, R. L., Fang, R., Dally, J., Briggs, M., Lundy, F. T., Kiapranis, R., et al. (2020). Evaluation of Cypholophus macrocephalus sap as a treatment for infected cutaneous ulcers in Papua New Guinea. Fitoterapia, 143, 104554. https://doi.org/https://doi.org/10.1016/j.fitote.2020.104554

Naumann, E. (2015). Eco labelling: overview and implications for developing countries. Acta Universitatis Agriculturae et Silviculturae Mendelianae Brunensis, 53(9), 1689-1699. https://media.africaportal. org/documents/DPRU_PB_01-P19.pdf

Naveen, B. P., Sumalatha, J., \& Malik, R. K. (2018). A study on contamination of ground and surface water bodies by leachate leakage from a landfill in Bangalore, India. International Journal of Geo-Engineering, 9(1), 27. https://doi.org/10.1186/s40703-018-0095-X

Noma, T., Ide, K., Yoshikawa, J., Kojo, K., Matsui, H., Nakajima, R., \& Imai, K. (2012). Development of waste gasification and gas reforming system for municipal solid waste (MSW). Journal of Material Cycles and Waste Management, 14(3), 153-161. https://doi.org/10.1007/s10163-012-0051-3

OECD. (2018). Improving plastics management: trends, policy responses, and the role of international cooperation and trade. Environmental Policy Paper No., 12(12), 20

Olay-Romero, E., Turcott-Cervantes, D. E., Hernández-Berriel, M. del C., Lobo-García de Cortázar, A., Cuartas-Hernández, M., \& de la Rosa-Gómez, I. (2020). Technical indicators to improve municipal solid waste management in developing countries: A case in Mexico. Waste Management, 107, 201210. https://doi.org/https://doi.org/10.1016/j.wasman.2020.03.039

Olley, J. E., IJgosse, J., Rudin, V., \& Alabaster, G. (2014). Developing a common framework for integrated solid waste management advances in Managua, Nicaragua. Waste Management \& Research, 32(9), 822-833. https://doi.org/https://doi.org/10.1177/0734242X14545640

Osra, F. A., Ozcan, H. K., Alzahrani, J. S., \& Alsoufi, M. S. (2021). Municipal solid waste characterization and landfill gas generation in kakia landfill, makkah. Sustainability (Switzerland), 13(3), 1-13. https:// doi.org/10.3390/su13031462

Ozkaya, B., Demir, A., \& Bilgili, M. S. (2007). Neural network prediction model for the methane fraction in biogas from field-scale landfill bioreactors. Environmental Modelling \& Software, 22(6), 815-822. https://doi.org/https://doi.org/10.1016/j.envsoft.2006.03.004

Pat, R. L. K. (2003). Customary land tenure in a changing context. In Second regional pacific meeting, September 7th - 9th, 2003 (Vol. 2). Brisbane, Australia: Department of lands \& physical planning. 
Pata, U. K. (2021). Linking renewable energy, globalization, agriculture, CO2 emissions and ecological footprint in BRIC countries: A sustainability perspective. Renewable Energy. https://doi.org/https:// doi.org/10.1016/j.renene.2021.03.125

Pierini, V. I., Mazzeo, N., Cazenave, M., \& Semmartin, M. (2021). Waste generation and pro-environmental behaviors at household level: A citizen science study in Buenos Aires (Argentina). Resources, Conservation and Recycling, 170, 105560. https://doi.org/https://doi.org/10.1016/j.resconrec.2021. 105560

Pirsaheb, M., Khosravi, T., \& Sharafi, K. (2013). Domestic scale vermicomposting for solid waste management. International Journal of Recycling of Organic Waste in Agriculture, 2(1), 4. https://doi.org/10. $1186 / 2251-7715-2-4$

Population Summary. (2018). National statistical office Papua New Guinea. https://www.nso.gov.pg/stati stics/population/. Accessed 6 Aug 2020.

Premakumara, D. G. J., Menikpura, S. N. M., Singh, R. K., Hengesbaugh, M., Magalang, A. A., Ildefonso, E. T., et al. (2018). Reduction of greenhouse gases (GHGs) and short-lived climate pollutants (SLCPs) from municipal solid waste management (MSWM) in the Philippines: Rapid review and assessment. Waste Management, 80, 397-405. https://doi.org/https://doi.org/10.1016/j.wasman.2018. 09.036

Pujara, Y., Pathak, P., Sharma, A., \& Govani, J. (2019). Review on Indian Municipal Solid Waste Management practices for reduction of environmental impacts to achieve sustainable development goals. Journal of Environmental Management, 248, 109238. https://doi.org/https://doi.org/10.1016/j.jenvm an.2019.07.009

Rasapoor, M., Young, B., Brar, R., \& Baroutian, S. (2020). Improving biogas generation from aged landfill waste using moisture adjustment and neutral red additive: Case study: Hampton Downs's landfill site. Energy Conversion and Management, 216, 112947. https://doi.org/https://doi.org/10.1016/j.encon man.2020.112947

Rastogi, M., Nandal, M., \& Khosla, B. (2020). Microbes as vital additives for solid waste composting. Heliyon, 6(2), e03343. https://doi.org/https://doi.org/10.1016/j.heliyon.2020.e03343

Rathore, P., \& Sarmah, S. P. (2020). Economic, environmental and social optimization of solid waste management in the context of circular economy. Computers \& Industrial Engineering, 145, 106510. https://doi.org/https://doi.org/10.1016/j.cie.2020.106510

Rathore, P., \& Sarmah, S. P. (2021). Investigation of factors influencing source separation intention towards municipal solid waste among urban residents of India. Resources, Conservation and Recycling, 164, 105164. https://doi.org/https://doi.org/10.1016/j.resconrec.2020.105164

Renou, S., Givaudan, J. G., Poulain, S., Dirassouyan, F., \& Moulin, P. (2008). Landfill leachate treatment: Review and opportunity. Journal of Hazardous Materials, 150(3), 468-493. https://doi.org/https:// doi.org/10.1016/j.jhazmat.2007.09.077

Rolewicz-Kalińska, A., Lelicińska-Serafin, K., \& Manczarski, P. (2020). The circular economy and organic fraction of municipal solid waste recycling strategies. Energies, 13(17). https://doi.org/https://doi.org/ 10.3390/en 13174366

Rovo, B. C. (2011). Household solid waste characterisation survey May 23 to 272011 J-PRISM Project Report.

Rudra, S., \& Tesfagaber, Y. K. (2019). Future district heating plant integrated with municipal solid waste (MSW) gasification for hydrogen production. Energy, 180, 881-892. https://doi.org/https://doi.org/10. 1016/j.energy.2019.05.125

Saadat, S., Rawtani, D., \& Hussain, C. M. (2020). Environmental perspective of COVID-19. Science of The Total Environment, 728, 138870. https://doi.org/https://doi.org/10.1016/j.scitotenv.2020.138870

Sampat, A. M., Hicks, A., Ruiz-Mercado, G. J., \& Zavala, V. M. (2021). Valuing economic impact reductions of nutrient pollution from livestock waste. Resources, Conservation and Recycling, 164, 105199. https://doi.org/https://doi.org/10.1016/j.resconrec.2020.105199

Sanger, M., Natarajan, B. M., Wang, B., Edil, T., \& Ginder-Vogel, M. (2020). Recycled concrete aggregate in base course applications: Review of field and laboratory investigations of leachate pH. Journal of Hazardous Materials, 385, 121562. https://doi.org/https://doi.org/10.1016/j.jhazmat.2019.121562

Sarkar, U., \& Hobbs, S. (2002). Odour from municipal solid waste (MSW) landfills: A study on the analysis of perception. Environment international, 27, 655-662

Scheutz, C., \& Kjeldsen, P. (2019). Guidelines for landfill gas emission monitoring using the tracer gas dispersion method. Waste Management, 85, 351-360. https://doi.org/https://doi.org/10.1016/j.wasman. 2018.12.048

Schwarzwälder Sprovieri, J. A., Octavio de Souza, T. S., \& Contrera, R. C. (2020). Ammonia removal and recovery from municipal landfill leachates by heating. Journal of Environmental Management, 256, 109947. https://doi.org/https://doi.org/10.1016/j.jenvman.2019.109947 
Shakya, P. R., Shrestha, P., Tamrakar, C. S., \& Bhattarai, P. K. (2008). Studies on potential emission of hazardous gases due to uncontrolled open-air burning of waste vehicle tyres and their possible impacts on the environment. Atmospheric Environment, 42(26), 6555-6559. https://doi.org/https://doi.org/10. 1016/j.atmosenv.2008.04.013

Sharma, K., \& Garg, V. K. (2019). Chapter 10 - vermicomposting of waste: A zero-waste approach for waste management. In M. J. Taherzadeh, K. Bolton, J. Wong, \& A. B. T.-S. R. R. and Z. W. A. Pandey (Eds.), (pp. 133-164). Elsevier. https://doi.org/https://doi.org/10.1016/B978-0-444-64200-4.00010-4

Soobhany, N. (2018). Remediation potential of metalliferous soil by using extracts of composts and vermicomposts from Municipal Solid Waste. Process Safety and Environmental Protection, 118, 285295. https://doi.org/https://doi.org/10.1016/j.psep.2018.07.005

Soobhany, N., Mohee, R., \& Garg, V. K. (2015a). Recovery of nutrient from Municipal Solid Waste by composting and vermicomposting using earthworm Eudrilus eugeniae. Journal of Environmental Chemical Engineering, 3(4, Part A), 2931-2942. https://doi.org/https://doi.org/10.1016/j.jece.2015.10.025

Soobhany, N., Mohee, R., \& Garg, V. K. (2015b). Comparative assessment of heavy metals content during the composting and vermicomposting of Municipal Solid Waste employing Eudrilus eugeniae. Waste Management, 39, 130-145. https://doi.org/https://doi.org/10.1016/j.wasman.2015.02.003

Soobhany, N., Mohee, R., \& Garg, V. K. (2015c). Experimental process monitoring and potential of Eudrilus eugeniae in the vermicomposting of organic solid waste in Mauritius. Ecological Engineering, 84, 149-158. https://doi.org/https://doi.org/10.1016/j.ecoleng.2015.08.003

SPREP. (2010). Pacific regional solid waste management strategy 2010-2015.

Stanley, R., Arpa, G., Sakulas, H., Harakuwe, A., \& Timi, D. (2013). Phytoremediation: An eco-friendly and sustainable method of heavy metal removal from closed mine environments in Papua New Guinea. Procedia Earth and Planetary Science, 6, 269-277. https://doi.org/https://doi.org/10.1016/j. proeps.2013.01.036

Su, G., Ong, H. C., Ibrahim, S., Fattah, I. M. R., Mofijur, M., \& Chong, C. T. (2021). Valorisation of medical waste through pyrolysis for a cleaner environment: Progress and challenges. Environmental Pollution, 279, 116934. https://doi.org/https://doi.org/10.1016/j.envpol.2021.116934

Sultan, Z., Bomoteng, J., Philemon, M., \& Yalehen, A. (2019). Public transportation improvement in PNG: A case study of Lae City. SSRN Electronic Journal. https://doi.org/10.2139/ssrn.3137404

Sunayana, K. S., \& Kumar, R. (2021). Forecasting of municipal solid waste generation using non-linear autoregressive (NAR) neural models. Waste Management, 121, 206-214. https://doi.org/https://doi. org/10.1016/j.wasman.2020.12.011

Taşkın, A., \& Demir, N. (2020). Life cycle environmental and energy impact assessment of sustainable urban municipal solid waste collection and transportation strategies. Sustainable Cities and Society, 61, 102339. https://doi.org/https://doi.org/10.1016/j.scs.2020.102339

The Circular Economy. (2017). https://www.ellenmacarthurfoundation.org/explore/the-circular-economyin-detail. Accessed 31 Jan 2021

Timmermans, B., \& Achten, W. M. J. (2018). From value-added tax to a damage and value-added tax partially based on life cycle assessment: principles and feasibility. The International Journal of Life Cycle Assessment, 23(11), 2217-2247. https://doi.org/10.1007/s11367-018-1439-7

Tsai, F. M., Bui, T.-D., Tseng, M.-L., Lim, M. K., \& Tan, R. R. (2021). Sustainable solid-waste management in coastal and marine tourism cities in Vietnam: A hierarchical-level approach. Resources, Conservation and Recycling, 168, 105266. https://doi.org/https://doi.org/10.1016/j.resconrec.2020.105266

Ugwu, C. O., Ozoegwu, C. G., \& Ozor, P. A. (2020). Solid waste quantification and characterization in university of Nigeria, Nsukka campus, and recommendations for sustainable management. Heliyon, 6(6), e04255. https://doi.org/https://doi.org/10.1016/j.heliyon.2020.e04255

UNESCAP. (2010). Guidelines for solid waste management assessment (Baseline Survey) in Secondary Cities and Small Towns in Asia and the Pacific. https://www.unescap.org/sites/default/files/Guidelines for Solid Waste Management Assessment (Baseline Survey) FINAL.pdf

Vaccari, M., Tudor, T., \& Vinti, G. (2019). Characteristics of leachate from landfills and dumpsites in Asia, Africa and Latin America: an overview. Waste Management, 95, 416-431. https://doi.org/https://doi. org/10.1016/j.wasman.2019.06.032

Walker, J. M. (1996). U.S. Environmental Protection Agency Regulations for Compost Production and Use BT-The Science of Composting. In M. de Bertoldi, P. Sequi, B. Lemmes, \& T. Papi (Eds.), (pp. 357369). Dordrecht: Springer Netherlands. https://doi.org/https://doi.org/10.1007/978-94-009-1569-5_34

Wang, P., Hu, Y., \& Cheng, H. (2019). Municipal solid waste (MSW) incineration fly ash as an important source of heavy metal pollution in China. Environmental Pollution, 252, 461-475. https://doi. org/https://doi.org/10.1016/j.envpol.2019.04.082

Wangi, T. (2013). Solid waste managemet in Papua New Guinea. National Research Institute. https://devpo licy.org/solid-waste-management-in-papua-new-guinea-20130812/ 
Wei, Y., Li, J., Shi, D., Liu, G., Zhao, Y., \& Shimaoka, T. (2017). Environmental challenges impeding the composting of biodegradable municipal solid waste: A critical review. Resources, Conservation and Recycling, 122, 51-65. https://doi.org/https://doi.org/10.1016/j.resconrec.2017.01.024

Wilson, D., Velis, C., \& Rodic-Wiersma, L. (2013). Integrated sustainable waste management in developing countries. Proceedings of the ICE - Waste and Resource Management, 166, 52-68. https://doi.org/10. 1680/warm.12.00005

Woodruff, A. (2014). Solid waste management in the Pacifi c Papua New Guinea Country Snapshot. https:// www.adb.org/publications/solid-waste-management-pacific-papua-new-guinea-country-snapshot

Yan, M., Antoni, Wang, J., Hantoko, D., \& Kanchanatip, E. (2021). Numerical investigation of MSW combustion influenced by air preheating in a full-scale moving grate incinerator. Fuel, 285, 119193. https://doi.org/https://doi.org/10.1016/j.fuel.2020.119193

Yoshinaga, J., Minagawa, M., Suzuki, T., Ohtsuka, R., Kawabe, T., Hongo, T., et al. (1991). Carbon and nitrogen isotopic characterization for Papua-New-Guinea Foods. Ecology of Food and Nutrition, 26, 17-25. https://doi.org/10.1080/03670244.1991.9991185

Zeng, W., Liu, J., Ma, H., Liu, Y., \& Liu, A. (2018). Experimental study on the flame propagation and laminar combustion characteristics of landfill gas. Energy, 158, 437-448. https://doi.org/https://doi.org/ 10.1016/j.energy.2018.06.062

Zhang, Z., Wang, J., Liu, L., Ma, J., \& Shen, B. (2020). Preparation of additive-free glass-ceramics from MSW incineration bottom ash and coal fly ash. Construction and Building Materials, 254, 119345. https://doi.org/https://doi.org/10.1016/j.conbuildmat.2020.119345

Ziraba, A. K., Haregu, T. N., \& Mberu, B. (2016). A review and framework for understanding the potential impact of poor solid waste management on health in developing countries. Archives of public health $=$ Archives belges de sante publique. African Population and Health Research Center, P. O. Box 10787-00100, Nairobi, Kenya. https://doi.org/https://doi.org/10.1186/s13690-016-0166-4

Publisher's Note Springer Nature remains neutral with regard to jurisdictional claims in published maps and institutional affiliations.

\title{
Authors and Affiliations
}

\section{Willie Doaemo ${ }^{1,2} \cdot$ Sahil Dhiman ${ }^{3,4}$ (D) Alexander Borovskis ${ }^{3,5} \cdot$ Wenlan Zhang ${ }^{3,6}$. Sumedha Bhat ${ }^{3,7}$. Srishti Jaipuriaa,8 Mirzi Betasolo $^{1}$}

Willie Doaemo

willie.doaemo@pnguot.ac.pg; morobedevelopmentfoundation@gmail.com

\author{
Alexander Borovskis \\ alex@helixos.co \\ Wenlan Zhang \\ wenlan.zhang19@imperial.ac.uk
}

Sumedha Bhat

sumedha_bhat@berkeley.edu

Srishti Jaipuria

srishti.jaipuria@gmail.com

Mirzi Betasolo

mirzi.betasolo@pnguot.ac.pg

1 Department of Civil Engineering, Papua New Guinea University of Technology, Lae 00411, Papua New Guinea

2 Morobe Development Foundation, Doyle Street, Trish Avenue-Eriku, Lae 00411, Papua New Guinea

3 United Nations Volunteering Program, Morobe Development Foundation, Lae 00411, Papua New Guinea 
4 Department of Mechanical Engineering, Thapar Institute of Engineering and Technology Patiala, Patiala, Punjab 147004, India

5 Helixos (Sydney), Sydney, Australia

6 Centre for Environmental Policy, Imperial College London, London, UK

7 Department of Chemistry, University of California, Berkeley, CA, USA

8 Urban Planning Department, College of Engineering, Pune, India 